\title{
Expedition 334 summary $^{1}$
}

\author{
Expedition 334 Scientists $^{2}$
}

\section{Chapter contents}

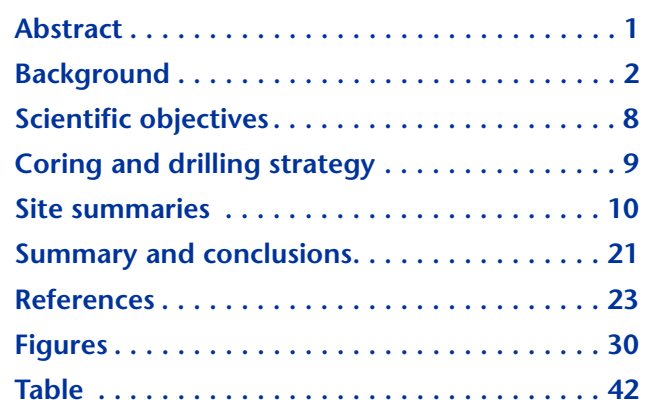

${ }^{1}$ Expedition 334 Scientists, 2012. Expedition 334 summary. In Vannucchi, P., Ujiie, K., Stroncik, N., Malinverno, A., and the Expedition 334 Scientists, Proc. IODP, 334: Tokyo (Integrated Ocean Drilling Program Management International, Inc.). doi:10.2204/iodp.proc.334.101.2012 'Expedition 334 Scientists' addresses.

\begin{abstract}
Integrated Ocean Drilling Program Expedition 334, also known as the Costa Rica Seismogenesis Project (CRISP), was designed to understand the processes that control nucleation and seismic rupture of large earthquakes at erosional subduction zones. CRISP involved the only known erosional end-member of convergent margins within reach of scientific drilling. With a relatively thin sediment cover, fast convergence rate, abundant seismicity, subduction erosion, and change in subducting plate relief along strike, CRISP offered excellent opportunities to learn the causes of earthquake nucleation and rupture propagation. This project complements other deep-fault drilling (San Andreas Fault Observatory at Depth and Nankai Trough Seismogenic Zone Experiment) and investigates the first-order seismogenic processes common to most faults and those unique to erosional margins. The primary goals of Expedition 334 were

- Characterization of lithological, physical, and frictional properties of upper plate material;

- Estimation of subduction channel thickness and the rate of subsidence caused by subduction erosion;

- Characterization of the fluid flow system and thermal structure of the erosive margin; and

- Determination of the change in the stress field across the updip limit of the seismogenic zone.

In order to accomplish these objectives, coring was conducted at three slope sites (Sites U1378 and U1380 on the middle slope and Site U1379 on the upper slope) and at one site on the Cocos plate (Site U1381). Expedition 334 is also the first step toward deep riser drilling through the aseismic and seismic plate boundary; both slope sites might serve as pilot holes for a potential future riserdrilling project. Sites U1378 and U1379 were first characterized by logging while drilling (LWD) to document in situ physical properties, stratigraphic and structural features, and stress state, in addition to continuous core sampling to the target depth. Cores were taken at both sites to examine slope sediment and the underlying upper plate basement. Coupling LWD data with data from sediment and basement samples provides important information about tectonic, hydrologic, and seismic features along this erosive convergent margin.
\end{abstract}




\section{Background}

\section{Subducting plate and the Cocos Ridge}

The oceanic Cocos plate subducting beneath Costa Rica was formed at two different spreading centers, the East Pacific Rise (EPR) and the Cocos-Nazca spreading center (CNS), and has been largely influenced by Galapagos hotspot volcanism. The largest feature formed by the passage of the Cocos plate over the Galapagos hotspot is the $2.5 \mathrm{~km}$ high Cocos Ridge (Fig. F1). The oceanic crust beneath the ridge is three times thicker than normal oceanic crust (25 km; Stavenhagen et al., 1998) and has a Galapagostype geochemical composition. Bordering the ridge to the northwest is regular CNS oceanic crust. Younger seamounts also being formed by the Galapagos hotspot cover $40 \%$ of this area of the Cocos plate (Fig. F1), resulting in a rather rough plate morphology. Further north, EPR-generated crust has a smoother morphology. The area drilled during Deep Sea Drilling Project (DSDP) Leg 84 and Ocean Drilling Program (ODP) Legs 170 and 205 (von Huene, Aubouin, et al., 1985; Kimura, Silver, Blum, et al., 1997; Morris, Villinger, Klaus, et al., 2003) lies just northwest of the EPR/CNS crustal boundary (Barckhausen et al., 2001). Sills with Galapagos-type geochemistry drilled at ODP Sites 1039 and 1253 show the great lateral extent of hotspot volcanism.

The influence of Cocos Ridge subduction increases from the Nicoya Peninsula in the northwest to the Burica Peninsula in the southeast ( $400 \mathrm{~km}$; Fig. F1) and is accompanied by morphologic changes along the margin in response to shallowing of the WadatiBenioff Zone. The seismically active slab dips at $\sim 65^{\circ}$ near the Nicaraguan border and shallows a few degrees inboard of the Cocos Ridge. The timing of the Cocos Ridge impinging on the Middle America Trench is an unresolved issue, with estimates ranging from 1 Ma (Hey, 1977; Lonsdale and Klitgord, 1978) to $\sim 5 \mathrm{Ma}$ (Sutter, 1985). The $5 \mathrm{Ma}$ age is based on the emplacement of adakitic arc rocks between 5.8 and 2.0 Ma (Abratis and Wörner, 2001) and thermochronological constraints on the uplift of the Talamanca Cordillera (Gräfe et al., 2002). However, marine deposition and volcanic flows in the Pliocene Terraba forearc basin directly inboard of the Cocos Ridge (Kolarsky et al., 1995) raise serious concerns about this model. A second question is when the Cocos Ridge started to form. Several investigators have proposed a date of $\sim 20-22 \mathrm{Ma}$, synchronous with the formation of the CNS (van Andel et al., 1971; Lonsdale and Klitgord, 1978); however, this remains an unresolved problem.

\section{Upper plate and onland geology}

Arcward of the Middle America Trench offshore the Osa Peninsula, the lower slope consists of a 10-12 $\mathrm{km}$ wide frontal prism (Fig. F2). A similar 3-5 km wide frontal prism is also present offshore the Nicoya Peninsula, where it is composed of slope sediment redeposited into the trench and buttressed against forearc basement. The forearc basement, although poorly sampled during Leg 170 , is generally accepted to be composed of the same igneous rock exposed onshore (Ye et al., 1996; Kimura, Silver, Blum, et al., 1997; Vannucchi et al., 2001). The igneous complexes exposed in Costa Rica represent parts of the Caribbean Large Igneous Province (CLIP) (emplaced between 74 and $94 \mathrm{Ma}$; Sinton et al., 1998) and accreted ocean islands and aseismic ridge terranes (Hauff et al., 1997, 2000; Sinton et al., 1997; Hoernle et al., 2002). Crucially, there is no evidence that the forearc is composed of a complex of tectonized sediment offscraped from the currently subducting plate, although the 60-65 Ma Quepos and Osa terranes are interpreted to reflect rocks accreted from subducted edifices generated by the Galapagos hotspot (Hauff et al., 1997; Vannucchi et al., 2006).

The forearc basement (Costa Rica Seismogenesis Project [CRISP] transect) southeast of the operation area of Legs 84, 170, and 205 is interpreted to be composed of a middle Eocene-middle Miocene mélange of oceanic lithologies accreted to the overriding plate (Vannucchi et al., 2006). The Osa Mélange, dominated by basalt, radiolarite, and limestone, is the most seaward unit exposed on land close to the CRISP transect. The nature and significance of the Osa Mélange remains a subject of debate. It has alternatively been interpreted as debris flows that were subsequently accreted to the margin (Buchs and Baumgartner, 2003), as a tectonic mélange produced by subduction erosion (Meschede et al., 1999), or as an old tectonic mélange developed within material that was accreted prior to the arrival of the Cocos Ridge (Vannucchi et al., 2006). There is no evidence to suggest that the Osa Mélange reflects accretion from the currently subducting plate, and the evidence for ongoing tectonic erosion of the forearc is compelling. The Osa Mélange is, to our best knowledge, the unit that forms the forearc basement, which we could expect to drill as upper plate basement during CRISP. A major unknown is the nature of the high-amplitude landward-dipping reflectors cutting through the forearc basement (Fig. F2). The reflectors branch upward from the plate interface similarly to "splay faults" (Park et al., 2002). Our interpretation, though, suggests that these surfaces 
represent old faults related to a middle Eocene-middle Miocene accretionary event, now sealed by the slope apron sediment. Only a few of these faults have been reactivated as normal faults, as indicated by offsets at the top of the forearc basement, similar to observations offshore the Nicoya Peninsula and Quepos (McIntosh et al., 1993; Ranero and von Huene, 2000). Thus, the lack of a clear thrust sequence argues against the presence of out-of-sequence thrusts cutting the submarine portions of the forearc.

Seismic reflectors extending into the forearc basement have been interpreted as faults that are potential planes of weakness, which could play a role in focusing the flow of fluids drained from the deeper part of the margin, as suggested by the high reflectivity and high heat flux. However, the nature of permeability along these discontinuities is unknown. Identifying the nature and age of the landward-dipping reflectors is fundamental to understanding the tectonic history and the modern functioning of the margin offshore of the Osa Peninsula. The near-orthogonal subduction of bathymetrically rough oceanic lithosphere along the northern flank of the Cocos Ridge imprints a distinctive style of deformation on the overriding Costa Rica forearc. The CRISP drilling area has experienced the subduction of the Cocos Ridge, which has caused

- The extinction of the arc volcanism and uplift of the Talamanca Cordillera;

- The inversion of the middle Eocene-Pliocene forearc basin, now exposed along the Fila Costeña, a fold and thrust belt with peak elevations of 1000-1500 m; and

- The exhumation of the Late Cretaceous-early Eocene ophiolitic rocks cropping out along the Gulfo Dulce and the middle Eocene-middle Miocene Osa Mélange.

In correspondence to the onland projection of the Cocos Ridge axis, mesoscale fault populations and field mapping record active shortening related to the Fila Costeña fold and thrust belt (Fisher et al., 2004). Magnitudes of shortening decrease northwest and southeast of the onland projection of the Cocos Ridge axis. Locally, the fold and thrust belt accommodates at least $36 \mathrm{~km}$ of post-middle Pliocene shortening, which translates to a shortening rate of $\sim 40 \mathrm{~mm} / \mathrm{y}$, or nearly $50 \%$ of the total plate convergence rate (Sitchler et al., 2007).

Across the northwest coast of the Osa Peninsula, uplifted late Quaternary marine deposits have been dated (Sak et al., 2004). These Quaternary deposits disconformably overlie exposures of semilithified late Tertiary and Quaternary sediments of the Charco Azul and Armuelles Formations and the
Paleogene Osa Mélange (Sprechmann, 1984; Corrigan et al., 1990; Di Marco et al., 1995; Vannucchi et al., 2006). Exposures of late Paleocene deposits inboard of the axis of the subducting Cocos Ridge provide a detailed record of a complex history of vertical tectonism. Uplifted accumulations of fining-upward marine sands indicative of increasing water depth were deposited during an interval of eustatic sea level fall. This complex, yo-yo-like history of rapid syndepositional subsidence followed by rapid uplift observed across the northwestern Osa Peninsula may be related to the morphology of the underthrusting Cocos plate (Sak et al., 2004). The permanent strain recorded by uplift of these Quaternary surfaces exceeds the predicted rebound of stored elastic strain released during subduction-zone earthquakes.

\section{Volcanic arc}

Throughout the Tertiary, and especially during the Miocene, frequent volcanism in Central America produced very large eruptions of highly siliceous magma (Sigurdsson et al., 2000; Jordan et al., 2006). The majority of this magma formed the ignimbrites that extend from southern Mexico to southern Nicaragua, forming the Central American highlands (Sigurdsson et al., 2000). Some of the Miocene ignimbrites are present as far south as Costa Rica (Vogel et al., 2004, 2006). At $\sim 8 \mathrm{Ma}$, the volcanic front in $\mathrm{Ni}$ caragua shifted, probably in response to a change of the subduction direction (Ehrenborg, 1996; Barckhausen et al., 2001; DeMets, 2001), to its present position. In contrast, the volcanic arc in Costa Rica and Guatemala has maintained a more or less stable position.

In Costa Rica, new ${ }^{40} \mathrm{Ar} /{ }^{39} \mathrm{Ar}$ dating indicates a maximum age of the volcanic arc of at least $24 \mathrm{Ma}$ (Gans et al., 2002). Plutons intruded the Talamanca Cordillera until the late Miocene ( $7 \mathrm{Ma})$ (Mora, 1979; Sutter, 1985; Gans et al., 2002), after which subductionrelated calc-alkaline magmatism diminished. Although normal arc magmatism ceased in southern Costa Rica and western Panama from the late Miocene to Pliocene (i.e., 6-3 Ma), backarc alkaline magmatism produced lava flows, dikes, and sills (Abratis and Wörner, 2001). Volumetrically insignificant Pliocene to Quaternary (5.8-2.0 Ma) volcanic rocks erupted just south of the central magmatic arc. These lavas have a trace element signature characterizing them as partial melting products of subducted oceanic crust with garnet residue, or adakites, and a plume-related isotope signature (Abratis and Wörner, 2001; Gans et al., 2002; MacMillan et al., 2004).

One of the few younger large-magnitude eruptions of central Costa Rica is represented by the $322 \mathrm{ka}$ Tiribí Tuff (Pérez et al., 2006). However, there are ad- 
ditional widespread Plinian fall deposits from Costa Rican volcanoes that can be identified in the marine sediment, although no onshore correlatives have been identified (Kutterolf et al., 2008).

Variations in the nature of the incoming plate, in crustal thickness and composition (von Huene et al., 1995; Barckhausen et al., 1998), and in the tectonic setting are accompanied by arc-parallel variations in the composition of the volcanic rocks (Carr, 1984; Feigenson and Carr, 1986; Carr et al., 1990, 2003, 2007; Patino et al., 1997, 2000; Hoernle et al., 2002; Feigenson et al., 2004) and the magnitudes of eruptions (Rose et al., 1999). Such compositional variations are very helpful when correlating volcanic depositions on land with marine ash beds (Kutterolf et al., 2008). Compositional differences like these probably also exist for the Neogene volcanism of Central America.

The arc volcanic rocks from Costa Rica have a composition that is similar to ocean-island basalt (OIB), resembling volcanic rocks found along the Galapagos hotspot (Reagan and Gill, 1989). The origin of this geochemical signature is discussed. Different models exist that favor the origin of this signature either by residual Galapagos-type mantle after formation of the large igneous province or flow of OIBtype astenospheric mantle: (1) through a slab window or (2) from the northwest margin of South America (Herrstrom et al., 1995; Abratis and Wörner, 2001; Feigenson et al., 2004). Others explain the OIB signature by subduction erosion of older Galapagos and CLIP terranes in the Costa Rican forearc (Goss and Kay, 2006) or by it being primarily derived from the subducting Galapagos hotspot track (Hoernle et al., 2008). Because the Galapagos hotspot tracks (and islands) are chemically zoned (Hoernle et al., 2000; Werner et al., 2003), radiogenic isotope ratios that are not modified by melting processes can be used to distinguish between magmas influenced by the seamount province and the Cocos and Coiba Ridges. These characteristics allow estimates of arc-parallel mantle flow rate in the wedge of $63-190 \mathrm{~mm} / \mathrm{y}$ from Costa Rica to Nicaragua (Hoernle et al., 2008)

The Central American volcanic arc was a high-priority study area of the Subduction Factory initiative of the US MARGINS program. Along this arc, variations in subduction dynamics result in sharp differences in the apparent depth of sediment transport, mirroring strong along-strike changes in trace element and isotopic chemistry, such as the ${ }^{10} \mathrm{Be}$ deficit in Costa Rican volcanoes (Morris et al., 2002).

The tephra stratigraphy preserved in the slope apron sediment offshore Osa, when compared to that already recovered offshore of the Nicoya Peninsula, will help in the along-strike reconstruction of the margin and will open a window into the processes linked to the volcanic arc shutdown.

\section{Subduction erosion}

Drilling and seismic data indicate active and longlived subduction erosion from Guatemala to Costa Rica (Ranero and von Huene, 2000; Ranero et al., 2000; Vannucchi et al., 2001, 2003, 2004). This interpretation is based on long-term subsidence of the continental slope offshore of Nicoya Peninsula. Leg 170 provided direct evidence of shallow-water sedimentary rocks, which are now located in $3900 \mathrm{~m}$ water depth on the forearc and mark the slope apronforearc basement unconformity, proving that the margin offshore Nicoya Peninsula has experienced a net loss of crust since $\sim 16 \mathrm{Ma}$ (Vannucchi et al., 2001). Detailed analysis of the benthic fauna preserved in the slope apron sediments from Legs 84 and 170 indicates that the slow background subsidence of $\sim 20 \mathrm{~m} / \mathrm{m}$.y. dramatically increased to $\sim 600$ $\mathrm{m} / \mathrm{m}$.y. starting at the Miocene/Pliocene boundary (Vannucchi et al., 2003). This acceleration in subsidence, linked to the arrival of the Cocos Ridge at the Middle America Trench (Vannucchi et al., 2003), is our best proxy for faster subduction erosion offshore the Osa Peninsula. Here, ridge subduction caused severe damage to the margin, as suggested by the disrupted topography (von Huene et al., 2000). The whole margin, in fact, has a broad concavity centered on the Cocos Ridge, reflecting the removal of material through ridge subduction. The slope offshore Osa has retreated as much as $20 \mathrm{~km}$ more than in the Nicoya area, where the subducting plate is smoother and the trench retreat has been estimated at $\sim 50 \mathrm{~km}$ since $16 \mathrm{Ma}$ (Vannucchi et al., 2001). The inner slope trench of Costa Rica is punctuated by subducted seamount tracks that reflect a net loss of material. There, particularly disrupted topography is present at the base of the slope and in the wake of seamounts.

The slope apron-forearc unconformity extends regionally across the igneous basement in northern Costa Rica and the middle Eocene-middle Miocene mélange in southern Costa Rica.

Offshore Nicaragua, subsidence driven by tectonic erosion triggered the development of the Sandino forearc basin (Ranero and von Huene, 2000; Ranero et al., 2000).

\section{Fluids and volatiles in the forearc}

Elevated methane concentrations in the bottom water have been observed along the entire Costa Rica margin, indicative of active fluid venting at the seafloor (Kahn et al., 1996; McAdoo et al., 1996; 
Bohrmann et al., 2002). Chemoautotrophic and methanotrophic communities mark cold seeps at numerous localities. These communities are particularly concentrated at the headwall scarps, where subducted seamounts have triggered fractures, slides, and slumps that break a low-permeability, shallow sediment carapace and allow ascending fluids to feed the cold-seep biota (Kahn et al., 1996; Bohrmann et al., 2002; Ranero et al., 2008). Mud volcanoes and mud diapirs have also been found offshore Costa Rica and Nicaragua, particularly across the middle slope, and are associated with a high density of chemosynthetic organisms. The chemistry of the pore fluids sampled at these midslope features is indicative of dehydration reactions at depth, suggesting they are associated with structures that enable effective transport of deep-sourced fluids (Shipley et al., 1992; Bohrmann et al., 2002; Grevemeyer et al., 2004; Hensen et al., 2004).

Coring and sampling during Leg 170 revealed freshened pore waters along the décollement and the upper fault zone in the prism, which also show elevated $\mathrm{Ca}, \mathrm{Li}$, and $\mathrm{C}_{3}-\mathrm{C}_{6}$ hydrocarbon concentrations and low $\mathrm{K}$ concentrations (Kimura, Silver, Blum, et al., 1997; Silver et al., 2000; Morris, Villinger, Klaus, et al., 2003). These fluids contrast with pore fluids from below the décollement and between the décollement and upper fault zone, which have near-seawater chemistry (Kimura, Silver, Blum, et al., 1997; Morris, Villinger, Klaus, et al., 2003). The downhole temperatures measured during Legs 170 and 205 are insufficient to support in situ mineral dehydration and generation of thermogenic methane. Collectively, the geochemical data in the décollement offshore Nicoya Peninsula indicate that this flow system is active and that a fraction of the fluid is derived from depths within the subduction zone where temperatures are $\sim 80^{\circ}-150^{\circ} \mathrm{C}$ (Chan and Kastner, 2000; Silver et al., 2000; Kastner et al., 2006; Solomon et al., 2009). The sharpness of the geochemical anomalies in the décollement and the estimated temperature of the fluid suggest updip flow from a source region $\sim 38-55 \mathrm{~km}$ landward of the trench at 9-14 km depth, near the updip limit of the seismogenic zone (Harris and Wang, 2002; Spinelli and Saffer, 2004; Kastner et al., 2006; Ranero et al., 2008).

During Leg 205, two sealed borehole hydrologic observatories (CORKs) were installed offshore Nicoya Peninsula to investigate the relationship between tectonics, fluid flow, and fluid composition (Jannasch et al., 2003; Morris, Villinger, Klaus, et al., 2003; Solomon et al., 2009). One of these CORKs was deployed at Site 1255 with downhole instrumentation designed to monitor formation fluid flow rates, composition, pressure, and temperature in a screened interval in the décollement. The other CORK was deployed at Site 1253 with downhole instrumentation to measure fluid pressure, temperature, and chemistry in the subducting igneous basement. The initial $2 \mathrm{y}$ record was recovered in September 2004, and a second record was recovered in February 2009. The long-term pore fluid pressure record at Site 1255 showed a near-steady-state pressure that was only moderately superhydrostatic with a pore pressure ratio $\left(\lambda^{*}\right)$ of $\sim 0.2$ (Davis and Villinger, 2006). The flow rates averaged $\sim 1.0 \mathrm{~cm} / \mathrm{y}$ during the 2002-2004 deployment period (Solomon et al., 2009). Two positive transients in fluid pressure, flow rates, and composition were observed along the décollement between 2002 and 2004 (Davis and Villinger, 2006; Solomon et al., 2009). Both transients coincided with onshore deformational events recorded at continuously monitored GPS stations on the Nicoya Peninsula 2 weeks prior to being recorded near the trench at the CORK (Protti et al., 2004). These two transients were the result of aseismic slip dislocations that propagated updip over the course of $\sim 2$ weeks, terminating before reaching Site 1255 and the trench (Solomon et al., 2009), and indicate that, at the Costa Rica subduction zone, slow slip events propagate through the seismogenic zone to the trench.

The importance of the hydrological activity in the subducting oceanic plate is just beginning to be appreciated (Silver et al., 2000; Fisher et al., 2003; Hutnak et al., 2008; Solomon et al., 2009; Harris et al., 2010a). Low heat flow values averaging $\sim 30 \mathrm{~mW} / \mathrm{m}^{2}$ exist in the EPR-generated crust offshore the Nicoya Peninsula (see "Heat flow") (Langseth and Silver, 1996; Fisher et al., 2003; Heesemann et al., 2006). These values reflect $<30 \%$ of the expected value from conductive lithospheric cooling models for $24 \mathrm{Ma}$ crust (Stein and Stein, 1994), indicating effective hydrothermal cooling of the upper oceanic crust with recharge and discharge zones occurring at distant igneous outcrops and seamounts (Fisher et al., 2003). This inference is corroborated by pore fluid chemical and isotopic profiles in basal sediments that return to approximate seawater values near the upper part of the igneous basement (Chan and Kastner, 2000; Silver et al., 2000; Morris, Villinger, Klaus, et al., 2003). In addition to the cooling effect, the vigorous lateral flow of seawater must also alter and hydrate the igneous crust, affecting chemical and isotopic mass balances as well as the transfer of volatiles through the subducting slab down to the depth of magma genesis.

The continuous fluid pressure, temperature, and chemistry records obtained from the CORK at Site 1253 show that the pressure in uppermost igneous 
basement is $\sim 6 \mathrm{kPa}$ subhydrostatic (Davis and Villinger, 2006), indicating that it is highly permeable. The average fluid flow rate measured at the Site 1253 CORK is $0.3 \mathrm{~m} / \mathrm{y}$, and the fluid chemistry in the basement indicates that the basement fluid is actually a mixture of seawater $(\sim 50 \%)$ and a subduction zone fluid originating within the forearc ( $50 \%)$ (Solomon et al., 2009). These results suggest that the uppermost basement offshore Nicoya Peninsula serves as an efficient pathway for fluid expelled from the forearc. Offshore Osa Peninsula, heat flow values are much higher than offshore Nicoya Peninsula (averaging $~ 130 \mathrm{~mW} / \mathrm{m}^{2}$ ) (von Herzen and Uyeda, 1963; Vacquier et al., 1967). The Cocos Ridge upper crust is well layered and probably very permeable (C.R. Ranero, pers. comm., 2003). The contribution from the lower plate to the fluid circulation could also be significant in the CRISP drilling area. Results from Expedition 334 will help clarify fluid sources and pathways in this segment of the Costa Rica margin.

\section{Seismic reflection data}

Seismic reflection images collected between Osa and the Cocos Ridge (Fig. F2) indicate a more stratified forearc basement and lower velocity material $(\sim 1 \mathrm{~km} / \mathrm{s})$ than equivalent areas along the Nicoya transect. The contact between the Osa Mélange and a separate forearc igneous basement is indicated in wide-angle seismic data, reflection data (Fig. F3), and magnetic modeling. Short-wavelength magnetic anomalies beneath the Osa continental shelf are interpreted as localized bodies of igneous rock mixed with sedimentary rocks (U. Barckhausen, unpubl. data). Dredged rock samples from the Cocos Ridge and related seamounts give ages of 13.0-14.5 Ma near the trench (Werner et al., 1999). This leaves a 45 m.y. gap in the geologic record between the Galapagos hotspot activity preserved in the Cocos Ridge and the CLIP (74-94 $\mathrm{Ma})$. Rocks emplaced during this interval may be partially recorded in rock accreted beneath the Osa continental slope-forearc (Hoernle et al., 2002).

\section{Heat flow}

Offshore Costa Rica regional values of heat flow show marked changes along strike. Offshore the northern Nicoya Peninsula, heat flow values are anomalously low compared to global averages of similarly aged crust and predictions based on conductive cooling models. In contrast, regional heat flow values offshore the southern Nicoya Peninsula and to the south are scattered, but the mean is consistent with conductive cooling models. Two heat flow surveys (Ticoflux I and II) mapped the thermal transition between these crustal regions seaward of the trench and found that the thermal transition was quite sharp, indicative of a shallow source and consistent with more vigorous circulation. Locally, the location of the thermal transition zone is influenced by the presence of seamounts that act as sites of recharge and discharge (Fisher et al., 2003; Hutnak et al., 2006, 2007). Detailed profiles along the margin were made by the R/V Meteor Cruise 54-2 from Nicaragua south to southern Costa Rica (Harris et al., 2010a). These values, coupled with an earlier survey (Langseth and Silver, 1996) and with values from Leg 170 (Ruppel and Kinoshita, 2000), document the thermal structure of the incoming plate and margin. Additionally, bottom-simulating reflector (BSR) depths used as a proxy for heat flow extend the spatial coverage of seafloor measurements. Comparisons of collocated seafloor heat flow measurements and BSR-derived heat flow are in excellent agreement, adding confidence to the use of BSRs as a heat flow proxy in this area (Harris et al., 2010a). The combination of these data shows the profound effect of fluid flow through faults that cut the margin and within the upper oceanic basement as the plate subducts (Harris et al., 2010a, 2010b). Temperatures beneath the midslope drilling sites are estimated to range between $60^{\circ}$ and $90^{\circ} \mathrm{C}$.

\section{Seismogenic zone and earthquakes}

CRISP Program A is preparatory for the seismogenic zone experiment and will define the tectonic reference for deeper drilling. A full overview of the seismogenesis studies offshore the Osa Peninsula is provided in the CRISP Complex Drilling Project documents (iodp.tamu.edu/scienceops/precruise/costarica/ 537A-Full5_Vannucchi.pdf and iodp.tamu.edu/ scienceops/precruise/costarica/537A-Add.pdf). Here we want to emphasize, using teleseismic waveform modeling, that the Mw 6.4 June 2002 underthrusting earthquake (including its aftershocks) (Fig. F4) occurred at a shallower depth $(\sim 9 \mathrm{~km})$ (S.L. Bilek, pers. comm., 2003; I. Arroyo, pers. comm., 2009) than the 1999 earthquake event to the north. This may reflect along-strike variations in the updip extent of the seismogenic zone or its transitional nature.

GPS measurements on land indicate high stress over the subducted Cocos Ridge with most of the plate interface in the seismogenic region, which is essentially fully locked (Dixon, 2003). In contrast, seismic profiles show fault geometries (i.e., angles between forethrusts, backthrusts, and the décollement) that suggest low values of plate boundary friction (von Huene et al., 2000, 2004; von Huene and Ranero, 2003). These values are comparable to the shear strength of marine sediments and are able to accommodate seafloor relief at the front of the margin 
without much deformation. Fluids draining from the subducting lower plate in Central America are sufficient to hydrofracture and mobilize about a $1-2 \mathrm{~km}$ thick and $20 \mathrm{~km}$ long section of the upper plate material every million years.

\section{Site survey data}

The regional framework of the Middle America Trench off Costa Rica is well known from investigations based on DSDP expeditions in the early 1980s (Aubouin, von Huene, et al., 1982; von Huene, Aubouin, et al., 1985) and subsequent drilling during ODP Legs 170 and 205 (Kimura, Silver, Blum, et al., 1997; Morris, Villinger, Klaus, et al., 2003). Recently, this region has been the focus area of two major scientific projects: the German Collaborative Research Center (SFB) 574 "Volatiles and fluids in subduction zones" (sfb574.ifm-geomar.de/home/) and the US MARGINS National Science Foundation program (www.nsf-margins.org/SEIZE/CR-N/CostaRica.html). The results are $>10,000 \mathrm{~km}$ of seismic data acquisition, detailed seismological studies, and extensive bathymetric imaging (swath bathymetry; Weinrebe and Ranero, in GeoMapApp (geomapapp.org/) and MARGINS Data Portal (www.marine-geo.org/portals/margins/) (Fig. F5). The extensive multibeam bathymetric mapping started after the results from Cruise SO-76 of the German R/V Sonne, which showed varying seafloor morphology from offshore the Nicoya Peninsula to offshore the Osa Peninsula (von Huene et al., 1995). The multibeam bathymetry is complemented by several traverses with a deep-towed instrument. The towed ocean bottom instrument (TOBI) sidescan sonar system of the Southampton Oceanography Centre was used during Cruise SO-163 in the spring of 2002 to detect active fluid flow at seafloor mounds and mass wasting offshore Costa Rica (Weinrebe and Ranero, 2003). Together with the results of the TOBI survey during Cruise SO-144 in 1999, much of the continental margin from Costa Rica to southeast Nicaragua was imaged at a resolution of $10 \mathrm{~m}$. Parts of that surveyed area were imaged at greater resolution using the GEOMAR DTS-1 deep-towed sidescan sonar system to map key areas with a resolution of better than $1 \mathrm{~m}$ (Klaucke et al., 2008; Petersen et al., 2009). Observations of the seafloor with a TV sled, gravity coring, and a TV-guided grab (Flüh et al., 2004) pinpointed areas of interest. Widespread mounds, some tens of meters high and a few hundred meters wide, have been monitored with current meters and hydrographic stations (Flüh et al., 2004). Outcropping carbonates on top and at the flanks indicate that these mounds are formed by chemoherm carbonates with abundant signs of fluid flow (Bohrmann et al., 2002; Hensen et al., 2004).

Two permanent seismological networks have recorded seismicity in the area for the last three decades. Because offshore coverage is necessary to obtain high-quality locations for earthquakes originating at the seismogenic zone, several marine seismological networks of ocean-bottom seismometers (OBS) and ocean-bottom hydrophones (OBH) have been deployed offshore Costa Rica. The Costa Rica Seismogenic Zone Experiment (CRSEIZE), run by the University of California Santa Cruz, University of California San Diego, Observatorio Vulcanologico y Sismologico de Costa Rica, and University of Miami, established two seismic networks off the Osa and Nicoya Peninsulas. The first network was a 3 month (September-November 1999) onshore and offshore deployment between Quepos and the north shore of the Osa Peninsula, which recorded aftershocks from the 20 August 1999 Mw 6.9 underthrust earthquake. The second network operated onshore and offshore the Nicoya Peninsula from December 1999 to June 2000 (Newman et al., 2002; DeShon et al., 2006). CRSEIZE also included GPS campaigns across Costa Rica (Norabuena et al., 2004). German SFB 574 and the Red Sismológica Nacional used Cruises SO-163, SO-173, and M-54 (Meteor) to deploy and recover two networks of OBS and land stations between the Nicoya and Osa Peninsulas, each running during a period of 6 months from April 2002 to March 2003 (Arroyo et al., 2009; Dinc et al., 2010). The first of these networks (April-October 2002) happened to record the Mw 6.4 main shock and $\sim 400$ aftershocks to the west of Osa Peninsula (AdenArroyo, 2008). The latter sequence surrounds the drilling area.

Geophysical data acquisition in the proposed Osa drilling area is extensive. Besides the already mentioned CRSEIZE transect (Newman et al., 2002; Norabuena et al., 2004), the proposed sites are positioned on an OBS/OBH seismic refraction transect across the entire onshore/offshore of Costa Rica (Ye et al., 1996; Stavenhagen et al., 1998) (Fig. F3), which was acquired in 1995/1996 during the Trans Isthmus Costa Rica Scientific Exploration of a Crustal Transect (TICOSECT) project. TICOSECT is coincident with three multichannel seismic reflection surveys. The first was shot in 1978 (IG2903 vessel Ida Green), later reshot by Shell Oil (Kolarsky et al., 1995), and shot again in 1999 (BGR99 vessel Prof. Polshkov) with a long streamer and an industry acquisition system (Fig. F6). More recently, from 2004 to 2006, the German project SFB 574 operated a transect of broadband seismological stations follow- 
ing the same orientation as TICOSECT (Dzierma et al., 2010).

During 1991 and 1992, the Sonne made two cruises (SO-76 and SO-81) that greatly expanded swath mapping, seismic reflection, and refraction coverage to $\sim 250 \mathrm{~km}$, extending from the Nicoya Peninsula to the southeast, where the crest of Cocos Ridge is subducting (Fig. F1). The interpretation of the seismic reflection data from Cruise SO-81 (Hinz et al., 1996) is complemented with data acquired in 1999. Two of the BGR99 records are processed in depth (Fig. F2) and the remainder in time domains. The principal site survey line is flanked on either side by two lines at $1 \mathrm{~km}$ spacing and then by lines at 2,5, and $10 \mathrm{~km}$ spacing (Fig. F6). Although these are the most revealing seismic images, other industry- and academic-acquired records in the area are numerous. Unfortunately, the resources are not available to process them to their full potential. Proposed sites have cross-lines of industry and academic heritage. Transducer and high-resolution sparker coverage are available. Magnetic and gravity data cover the area (Barckhausen et al., 1998, 2001). GPS geodesy has been studied for more than a decade, and results show a locked Osa Peninsula area (LaFemina et al., 2009).

\section{Scientific objectives}

The targets of Expedition 334 were the slope sediments and the shallow portion of the upper plate basement in the Costa Rica erosive subduction system. The scientific objectives of LWD and coring at the two slope sites are the following:

\section{Estimate the composition, texture, and physical and frictional properties of the upper plate material.}

The upper plate material at erosive convergent margins is transported into the subduction channel, and consequently into the seismogenic zone, by upward migration of the plate boundary. The onset of seismogenic behavior along the subduction thrust is influenced by the physical and frictional properties of the overriding plate material. Geologic and experimental characterization of the upper plate basement is needed to provide structural and mechanical constraints on the possible changes in frictional behavior across the updip limit of the seismogenic zone. Sampling rocks of the upper plate basement beneath the upper slope is also useful to define drilling conditions for deep holes.

\section{Quantify subduction channel thickness and the rate of subduction erosion.}

The actively slipping plate boundary interface is located within the subduction channel. Determination of the thickness of the subduction channel is critical for preparatory structural geology work and the concept of describing the active slip surface and the damage zone for the deep riser drilling. To estimate the thickness of the subduction channel, namely the zone of broken upper plate material currently subducting, we need quantification of mass removal in the CRISP study area. A two-point recovery of fossiliferous sediments across the margin allows the crustal loss rate to be determined through the evaluation of a subsidence profile. Offshore Nicoya, the estimated volume of eroded upper plate rock carried down the subduction zone is essentially four times the volume of subducted trench sediment. Along the CRISP transect we expect the process to be accelerated, possibly as a result of the subduction of the Cocos Ridge.

\section{Characterize fluid/rock interaction, the hydrologic system, and the geochemical processes active within the upper plate.}

We expect that the Cocos Ridge subduction caused extensive fracturing of the upper plate that modified the hydrological system (e.g., flow paths, flow rates, heat flow, and mass transport). Landward-dipping reflectors cutting through the upper plate have been interpreted to connect all the way to the plate boundary. Geochemistry can open a window directly to the seismogenic zone through the analysis of parameters that can be related to chemical reactions occurring at seismogenic depths. Fluids are also highly relevant to seismicity because fluid pressure is a key parameter defining the stress state of the formation. Fluid pressure and temperature control the strength and frictional behavior of the rocks. Stress state and deformation processes, in turn, influence porosity and permeability and, consequently, fluid pressure. Hence, measuring the thermal and hydrologic regime is critical. Fluid pressure and temperature may be measured in situ until a depth where the material is semiconsolidated. Laboratory analysis, such as consolidation tests, can give indirect but realistic values of pore pressure.

\section{Measure the stress field and the heat flow along the updip limit of the seismogenic zone.}

The stress field may be inferred from borehole breakouts obtained by LWD. Both GPS investigations and the pattern of microearthquake epicenters indicate a highly stressed area in the vicinity of the Osa Peninsula, implying that relative plate motion in the seismogenic zone is primarily accommodated by coseismic frictional slip. Drilling will contribute to a better definition of the orientation of the horizontal compressive stress in the area. Downhole in situ heat 
flow measurements will improve our understanding of the thermal regime, allowing better temperature estimates associated with the onset of seismicity as well as allowing us to develop viscoelastic models of deformation.

Expedition 334 is also considered a stand-alone project providing data to solve long-standing problems related to the tectonics of the region. These primary objectives are

- To determine the Cocos Ridge subduction arrival time and its effects on the margin tectonics (e.g., acceleration of tectonic erosion processes);

- To examine the evolution of the Central American Volcanic Arc, of which the most relevant effects would be the timing of the progressive shut off of the volcanic arc and the uplift of the Talamanca Cordillera; and

- To determine the time progression of the death of a volcanic arc and its potential late products. This subject can be explored in detail because we would have at least two sedimentary columns to correlate events and thereby explore the consequences of the time-progressive subduction of the Cocos Ridge.

\section{Coring and drilling strategy}

The main aim of Expedition 334 is the thorough characterization of the sediment coverage and basement in at least two different sites along the Costa Rica erosive margin offshore the Osa Peninsula: Site U1379 (proposed Site CRIS-4A, alternate Site CRIS11A) above the locked portion of the subduction zone and Site U1378 (proposed Site CRIS-3B, alternate Site CRISP-10A) above the unlocked portion of the subduction zone. Generally, these objectives involved logging and coring as much of the sedimentary sequence and the basement at both sites as possible in the specified time window, and drilling operations were adjusted accordingly (Table T1).

The originally proposed drilling strategy determined at the precruise meeting in College Station, Texas (USA), in May 2010 was to begin drilling at Site U1378 followed by Site U1379 and to core two holes at the each site. At both sites, we planned to core the first hole (Hole A) with the advanced piston coring (APC) system to refusal, followed by extended core barrel (XCB) coring to refusal. The estimated refusal depth was $\sim 500$ meters below seafloor (mbsf). We planned to drill the second hole (Hole B) at both sites to a depth slightly above the refusal depth of Hole A (e.g., $490 \mathrm{mbsf}$ ), followed by rotary core barrel (RCB) coring to the target depth $(\sim 950-1000$ mbsf). While drilling/coring, we planned to take a number of advanced piston coring temperature tool (APCT-3) and Sediment Temperature Tool (SET)/sediment temperature pressure (SET-P) probe measurements to calculate temperature and pressure gradients at both sites. Core orientation measurements with the Flexit tool were also planned for the APCcored sections at each site.

The downhole logging program of Expedition 334 was designed to complement the core sample record at both sites by measuring continuous, in situ profiles of physical properties such as bulk density, porosity, resistivity, and natural gamma radiation. In addition to these formation properties, downhole logging provides oriented images of the borehole wall that are useful for determining the directions of bedding planes, fractures, and borehole breakouts. In the conventional technique of wireline logging, downhole measurements are taken by tools lowered in a previously drilled borehole. Wireline logging has had limited success in deep holes in unconsolidated clastic sequences because these holes tend to be unstable after drilling. It may be difficult to lower wireline tools in an unstable borehole, and hole irregularity can compromise the quality of the measurements. In LWD, downhole measurements are taken by instrumented drill collars in the bottom-hole assembly (BHA) near the drill bit. Hence, LWD measurements are made shortly after the hole is drilled and before the adverse effects of continued drilling or coring operations. LWD has been successful in previous scientific drilling expeditions to convergent margins such as Nankai during ODP Leg 196 and IODP Expeditions 314 and 319 (Mikada, Becker, Moore, Klaus, et al., 2002; Kinoshita, Tobin, Ashi, Kimura, Lallemant, Screaton, Curewitz, Masago, Moe, and the Expedition 314/315/316 Scientists, 2009; Saffer, McNeill, Byrne, Araki, Toczko, Eguchi, Takahashi, and the Expedition 319 Scientists, 2010), Barbados during ODP Legs 156 and 171A (Shipley, Ogawa, Blum, et al., 1995; Moore, Klaus, et al., 1998), and Costa Rica during ODP Leg 170 (Kimura, Silver, Blum, et al., 1997). LWD was selected as the logging technique for Expedition 334. The LWD equipment used during this expedition was provided by Schlumberger Drilling and Measurements under contract with the Lamont-Doherty Earth Observatory Borehole Research Group.

The Schlumberger LWD tools used during Expedition 334 were the geoVISION 675 (near-bit electrical resistivity, resistivity images, and natural gamma radiation), the arcVISION 675 (annular borehole pressure, resistivity, natural gamma radiation), the adnVISION 675 (bulk density, neutron porosity, an density and ultra- 
sonic caliper), and the measurement-while-drilling (MWD) TeleScope 675. Detailed descriptions of all downhole logging tools can be found at iodp.ldeo.columbia.edu/TOOLS_LABS/index.html.

In addition to collecting drilling mechanics data, the MWD tool also transmits a limited LWD data set by acoustic telemetry to the surface for real-time monitoring. The real-time measurements included the pressure of the borehole fluid in the annulus (the space between the drill string and the borehole wall). During Expedition 334, annular pressure was monitored while drilling to ensure that free gas did not enter the borehole.

During Expedition 334, LWD measurements were planned to be made in a dedicated hole drilled first at each site. The advantage of this strategy is that detailed physical property logs are available to optimize coring in subsequent holes. The operations plan estimated $\sim 3$ days/hole for LWD. This time allows for logging the whole sediment section at expected rates of penetration (ROPs) of $\sim 20 \mathrm{~m} / \mathrm{h}$. These are "gross" ROPs that include time for pipe connections. The allotted time is enough to reach the total depth objective in each hole if ROPs in the basement interval can be maintained at $\sim 10 \mathrm{~m} / \mathrm{h}$. If ROPs in the basement are significantly slower, the plan was to $\log$ as much as possible of the basement interval given the time constraint of $\sim 3$ days per LWD hole.

\section{Site summaries}

\section{Site U1378}

Site U1378 was drilled into the middle slope of the Costa Rica margin, $41 \mathrm{~km}$ offshore Osa Peninsula along BGR99 Line 7 (Fig. F2). The site is located above the unlocked portion of the plate boundary as defined by interplate earthquake relocation and geodetic measurements (S.L. Bilek, pers. comm., 2003; LaFemina et al., 2009). The margin here consists of an upper plate basement underlying about $750 \mathrm{~m}$ of slope sediments. The seismic sections show that this site is above the seaward edge of one of the high-amplitude reflectors interpreted as displacement surfaces. Site U1378 was designed to penetrate one of these surfaces. The primary purpose of drilling Site U1378 was to determine the nature, composition, and physical properties of the upper plate basement and to understand the nature of the landward-dipping seismic reflectors. Two holes were drilled at this site, Holes U1378A and U1378B, penetrating 456.9 and $523.9 \mathrm{~m}$ into the seafloor, respectively. Hole U1378A was dedicated to LWD operations to measure the in situ physical properties of the material in the borehole. Hole U1378B was designed to retrieve as much of the sediment coverage and basement as possible within the specified time window. Overall,
$526.39 \mathrm{~m}$ of sediment was retrieved with an average total recovery of $100.48 \%$. The basement was not reached in any of the holes because drilling was terminated early as a result of unfavorable hole conditions.

Based on lithologic characteristics, the sediment recovered at Site U1378 can be divided into two main lithostratigraphic units (Fig. F7). Unit I, $\sim 128 \mathrm{~m}$ thick, is composed of mainly soft, dark greenish gray, terrigenous silty clay. Intercalated in this silty clay is a series of $\sim 5 \mathrm{~cm}$ thick fining-upward sequences consisting of lithic sands and 21 tephra layers ranging in thickness from 0.5 to $7 \mathrm{~cm}$. The basal boundary between the silty clay and the sand and tephra sequences are sharp, whereas the top boundaries are gradational. Unit II, $\sim 385.73 \mathrm{~m}$ thick, consists predominantly of massive, well consolidated, olivegreen terrigenous clayey silt(stone) and silty clay(stone) with minor layers of sand(stone), sandy silty clay(stone), clay, clayey silt(stone), and 61 tephra layers that remain unlithified to $560 \mathrm{mbsf}$. The basal contact between the background sedimentation and the tephra layers is sharp, whereas the top contact is gradational. Within this monotonous sequence, sandy intervals become thicker and more common with depth. Throughout all of Unit II, fining- and coarsening-upward decimeter-scale sequences of sand are present. In the coarser sand layers, rip-up clasts, rounded clay lenses, and abundant shell fragments are commonly observed. Framboidal pyrite was observed in many of the smear slides throughout Unit II. Horizons of abundant calcareous concretions or lithified carbonate mud clasts are rare and concentrated within a $2 \mathrm{~m}$ interval of Core 334U1378B-27X (Sections 27X-4 through 27X-CC; 222.08-224.41 mbsf).

The 82 identified tephra layers seem to be quite heterogeneous in composition: 30 are light gray to pinkish/brownish white felsic tephras, 40 are pinkish gray/brown more mafic tephras, and 12 are pinkish/ greenish black mafic tephras. Mafic tephra beds account for $\sim 15 \%$ of the total tephra bed assemblage in Hole U1378B. The felsic tephra layers are mainly ( $>90 \mathrm{vol} \%$ ) composed of fresh, clear, colorless, fine to coarse ash-sized glass shards varying from angular blocky, cuspate, flat, and Y-shaped shards with nearly no bubbles to highly vesicular, pumiceous textures with many elongated bubbles. Dark gray mafic ash layers consist predominantly of dark to light brown glass shards. Most of the glass shards have blocky shapes and are medially to poorly vesicular and show strong signs of alteration, especially in the deeper part of the hole.

Generally, the sediment cored in Hole U1378B is characterized by low-angle bedding planes $\left(<30^{\circ}\right)$ as 
well as by healed and open faults with relatively steep dipping angles. Sediment-filled vein structures were observed from 262.2 mbsf downward. The main fault populations, characterized by zones of intense brecciation and sediment deformation, occur at 279.2-281.4, 361.9-376.5, 475.9-477.2, and 514.2 mbsf to an unknown lower boundary. The second fault zone shows the most intensive deformation and corresponds to a low-density/high-porosity interval identified by LWD.

Preliminary X-ray diffraction (XRD) analysis of the sediment suggests that there is little variation in mineralogical composition among the different lithostratigraphic units. XRD data indicate that the major mineral components are clay minerals including illite, smectite, kaolinite, and attapulgite, as well as calcite, anorthite, and quartz. Amphibole (hornblende and richterite), chlorite, pyroxene (augite and hypersthene), olivine, and pyrite peaks are present.

The physical property data obtained from cored material display expected behavior with depth and reflect the different units cored (Fig. F7). Physical property measurements were made after sediment cores reached thermal equilibrium with ambient temperature at $\sim 20^{\circ} \mathrm{C}$. Wet bulk density values increase with depth, likely a result of dewatering caused by overburden pressure and are well described by a linear trend. A small offset in wet bulk density values marks the boundary between lithostratigraphic Units I and II. Grain densities are relatively constant with depth, with an average value of $2.7 \mathrm{~g} / \mathrm{cm}^{3}$; however, they are quite variable in Unit II, ranging between 2.5 and $2.9 \mathrm{~g} / \mathrm{cm}^{3}$. There is no discernible offset between values characterizing lithostratigraphic Units I and II. On the whole, these values suggest a terrigenous origin. Porosity, inversely correlated with bulk density, decreases from $\sim 70 \%$ at the seafloor to $40 \%$ at the bottom of the hole. A slight increase in porosity between Units I and II corresponds to the decrease in wet bulk density at this boundary. An increase of porosity is observed at $\sim 40 \mathrm{mbsf}$ and corresponds to a sandy interval. Porosity increases a few percent between $\sim 480$ and 529 mbsf and may correspond to a decrease in the clay content. Magnetic susceptibility in the sedimentary sequence is low, indicating an abundance of noniron-bearing clays and scarcity of magnetic minerals. However, a region of generally higher values is present between $\sim 85$ and 195 mbsf. Other notable regions of relatively high values occur at $335,355,440$, and 460 mbsf. These excursions show high-wave number variability and may be due to lithologic variations between sands, silts, and clays. NGR values indicate a small positive trend through lithostrati- graphic Unit I and are relatively constant through Unit II. Notable excursions to higher values in Unit II occur at 200 and 480 mbsf. The lowermost NGR high is associated with scoria and a high abundance of mafic glass particles. Thermal conductivity values generally increase with depth and inversely correlate with porosity. In the upper $100 \mathrm{mbsf}$, variability is significant and likely reflects gas concentrations in the core. Downhole temperature measurements using the APCT-3 show a linear equilibrium temperature increase. Coupled with the average bottom water temperature and thermal conductivity measurements, these temperature data give a leastsquares geothermal gradient of $51.4^{\circ} \mathrm{C} / \mathrm{km}$ and a heat flow of $44 \mathrm{~mW} / \mathrm{m}^{2}$. This value is consistent with forearc values of heat flow.

Generally, all the observations summarized above are consistent with changing depositional conditions in a more downslope environment. The cover sequence recovered from Hole U1378B is a terrestrially sourced slope sequence that is consistent with high sedimentation rates throughout the depositional interval. Recognition of wood debris and thin layers $(<5 \mathrm{~cm}$ thick) of normal graded sands with sharp erosional bases within Unit I at this site is consistent with deposition in the distal facies of a clastic turbidite sequence.

This similarity is also consistent with the results of shipboard studies of calcareous nannofossils and foraminifers. Biogenic components in the cored sediment have a bimodal distribution in Unit II. Whereas shell fragments, diatoms, and nannofossils are sparse but ubiquitous throughout the unit, foraminifers are partly enriched within the sediment and are a major constituent of the sand-sized fraction. Based on nannofossil biostratigraphy, the sediment of the basal core was most likely deposited in the lower Pleistocene; thus, the sediments throughout the core are younger than $2 \mathrm{Ma}$. The sequence between 5.36 and 224.39 mbsf is assigned to undifferentiated Zones NN21-NN20 of the late to middle Pleistocene based on the presence of Emiliania huxleyi in Sample 334-U1378B-1H-CC (5.36 mbsf) and the absence of Pseudoemiliania lacunosa. Good preservation allows tentative identification of $E$. huxleyi in Sections 1H-CC (5.36 mbsf) through 16H-CC (127.91 mbsf). Samples 28X-CC (237.47 mbsf) through 63X-CC are assigned to Zone NN20 based on the last occurrence (LO) of P. lacunosa in Sample 28X-CC (237.47 mbsf) and the absence of Discoaster brouweri. Sample 57X-CC (476.18 mbsf) contains the first occurrence of early Pleistocene marker Helicosphaera sellii. Dominant species include Helicosphaera carteri, Gephryocapsa oceanica, Gephryocapsa caribbe- 
anica, Gephryocapsa small, and Calcidiscus leptoporus. Thus, average sedimentation rates are $\sim 516$ and 236 $\mathrm{m} / \mathrm{m}$.y. in the upper (<237 mbsf) and lower parts (237 524 mbsf) of the hole, respectively.

Although the boundaries of planktonic foraminiferal zones were not established, a few occurrence horizons of index species are approximately concordant with nannofossil zonation. Planktonic foraminifers, which are common to rare in the upper part of Hole U1378B, are mainly dominated by tropical fauna such as Globigerinoides quadrilobatus (Globigerinoides sacculifer), Globigerinoides ruber, Orbulina universa, Globorotalia menardii, and Neogloboquadrina dutertrei. Two index marker species of planktonic foraminifers were identified in limited horizons. Sample 334U1378B-5H-CC (43.77 mbsf) contained pink G. ruber (last appearance at $0.12 \mathrm{Ma}$ ), whereas Sample $4 \mathrm{H}-\mathrm{CC}$ (34.62 mbsf) did not contain the pink specimen. Thus, marine isotope Stage 5e is located in the interval between these two samples, and the horizons are assigned to foraminiferal Zone PT1. Coiling change of Pulleniatina from sinistral to dextral was observed in Samples 42X-CC (351.71 mbsf) through 30X-CC ( 245.19 mbsf). Thus, the sediment from Section $42 \mathrm{X}$ CC is older than $0.8 \mathrm{Ma}$.

Benthic foraminifers are abundant in the upper part of Hole U1378B; abundances in the lower parts are variable and range from common to rare. Generally, the majority of the observed benthic foraminiferal species is similar to modern assemblages, which are characteristic for the oxygen minimum zone in this region. Thus, the benthic foraminiferal community observed in the sediment of this hole is dominated by bathyal species. In general, the upper part of cored sediment at this site contains Pseudoparrella bradyana, Trifarina carinata, Valvulineria inflata, Cassidulina limbata, Uvigerina, and Gyroidina. Bolivina is characteristic for the upper to middle bathyal environment. In contrast to this, the sediment of the lower part of this site (>209.28 mbsf) contains species characteristic of a greater water depth (Uvigerina hispida, Melonis barleeanus, Gyroidina, and Oridorsalis umbonatus). Generally, the faunal changes observed at this site reflect continuous environmental changes from upper slope to middle slope.

Paleomagnetic investigations partially support Pleistocene deposition ages of the cored sediment. Remanent magnetization was measured on archive-half cores and discrete samples taken from the working half recovered from Hole U1378B. All archive-half cores were demagnetized in an alternating field (AF) to $15 \mathrm{mT}$ and measured with the pass-through magnetometer, whereas discrete samples were subjected to complete stepwise AF demagnetization and measured in both the SRM and a JR6 magnetometer. Cores $334-\mathrm{U} 1378 \mathrm{~B}-1 \mathrm{H}$ through $16 \mathrm{H}$ were cored with the APC system using a nonmagnetic cutting shoe and oriented with the Flexit orientation tool. Cores $17 \mathrm{X}$ through $63 \mathrm{X}$ were cored with the XCB system using a standard cutting shoe. For the APC cores, inclination data from neither archive half sections nor discrete sample measurements show any sign of reversed polarity magnetization. Declination data corrected by the Flexit tool cluster near present-day geomagnetic north. Thus, the sediments in the APC cores $(<127.8 \mathrm{mbsf})$ were deposited within the Brunhes period $(<0.78 \mathrm{Ma})$. This age assignment is consistent with the shipboard micropaleontological data, which suggest that the foraminifer fossil G. ruber (pink) found in Core 334-U1378B-5H may be 0.125 Ma in age. Paleomagnetic measurements on the XCB cores are severely affected by drilling-induced remagnetization and are inconclusive, but so far they have not revealed any reversed polarity. NRM intensities correlate with magnetic susceptibility data, suggesting some of the downhole susceptibility variation reflects change in magnetic minerals.

The geochemical trends displayed by the analyzed pore water (82 whole rounds) and gas samples (65 headspace samples, 99 void gas samples, and 173 gas samples) reflect in situ diagenetic reactions as well as fluid migration (see Figs. F16 and F17 in the "Site U1378" chapter, Figs. F22 and F23 in the "Site U1379" chapter, Figs. F7 and F8 in the "Site U1380" chapter, and Fig. F13 in the "Site U1381" chapter [Expedition 334 Scientists, 2012a, 2012b, 2012c, 2012d]). The profiles of sulfate, alkalinity, ammonium, methane, and calcium in the upper $20 \mathrm{mbsf}$ at this site reflect typical changes associated with organic carbon cycling. Sulfate concentration decreases almost linearly from the seafloor to the sulfate-methane transition zone (SMTZ) at 13 mbsf, whereas alkalinity increases from seawater value at the seafloor to a maximum at 24 mbsf. Likewise, ammonium concentration increases in the zone of active $\mathrm{SO}_{4}$ reduction and reaches a local maximum below the SMTZ at 24 mbsf, reflecting ongoing organic matter diagenesis. Calcium concentrations decrease from seawater value at the seafloor in this zone, reflecting precipitation of authigenic carbonates. The highest methane concentrations are observed just below the SMTZ between 14.1 and 23.6 mbsf. The gas at these depths results from biogenic production, as indicated by the high ratio of methane to heavier homologues (ethane and propane), with $\mathrm{CH}_{4} /\left(\mathrm{C}_{2} \mathrm{H}_{6}+\mathrm{C}_{3} \mathrm{H}_{8}\right)$ values ranging from 8,000 to 15,000 . From 20.7 to $200 \mathrm{mbsf}$, the ratio mainly steadily decreases and is interpreted as a mixing zone between shallow biogenic and deep-sourced thermogenic gas transported upward by diffusion.

From 100 to $\sim 440 \mathrm{mbsf}$, salinity, $\mathrm{Cl}, \mathrm{Mg}, \mathrm{K}$, and $\mathrm{Na}$ concentrations mainly show a monotonic decrease 
with depth (Fig. F7). Dissolved Ca concentration is variable to $\sim 200$ mbsf and increases with depth to a peak concentration at 440 mbsf that is coincident with minima in $\mathrm{Cl}, \mathrm{Mg}$, and $\mathrm{K}$ concentrations. Collectively, the pore fluid chemical profiles suggest there is a unique fluid between 420 and 500 mbsf characterized by relatively low salinity, $\mathrm{Cl}, \mathrm{Mg}, \mathrm{K}$, and alkalinity concentrations and elevated $\mathrm{Ca}$ concentration. This depth interval also corresponds to a marked increase in thermogenic hydrocarbons (propane, $n$-butane, and iso-butane). The in situ temperature at this depth is too cold for local generation of thermogenic hydrocarbons, suggesting lateral migration of a fluid sourced in a region with temperatures high enough to support clay dehydration and thermogenic hydrocarbon production.

The three samples recovered below 500 mbsf show steep depth gradients in salinity and chloride, indicating diffusional communication with another fluid below the cored section. Since the $\mathrm{Cl}$ and salinity profiles decrease below 500 mbsf, this fluid must be fresher than the deeper sourced fluid sampled between 420 and 500 mbsf. Ethane, propane, and isoand $n$-butane all show maxima at 518.7 mbsf. Corresponding with the increasing concentrations and maxima of these higher chain hydrocarbons $\left(\mathrm{C}_{2+}\right)$, the $\mathrm{CH}_{4} /\left(\mathrm{C}_{2} \mathrm{H}_{6}+\mathrm{C}_{3} \mathrm{H}_{8}\right)$ ratios indicate the dominance of thermogenic gas at depth in Hole U1378B.

Results from LWD generally correspond to the lithostratigraphic observations as well as to the physical property data obtained from the cored sediment. The LWD tools deployed in the hole included the adnVISION 675 (density, neutron, and ultrasonic caliper), the TeleScope 675 (MWD; power and data transmission and drilling parameters), the arcVISION 675 (propagation resistivity, gamma radiation, and annular pressure), and the geoVISION 675 (resistivity images and gamma radiation). The measurements recorded by the LWD tools were downloaded and processed successfully, except for the geoVISION resistivity image data.

Two logging units were defined on the basis of the LWD measurements. Logging Unit 1 (0-82 mbsf) corresponds to a compacting sequence where density and resistivity increase and porosity decreases with depth, reaching $1.6 \mathrm{~g} / \mathrm{cm}^{3}, 1 \Omega \mathrm{m}$, and $60 \%$ porosity at the base of the unit. The top of logging Unit 2 (82-455 mbsf) is marked by a step increase in density and resistivity, which then increase slowly with depth (from $1.8 \mathrm{~g} / \mathrm{cm}^{3}$ and just above $1 \Omega \mathrm{m}$ at the top to $1.9 \mathrm{~g} / \mathrm{cm}^{3}$ and just below $2 \Omega \mathrm{m}$ at the bottom of the unit). Porosity shows a matching small decrease with depth, from $55 \%$ at the top of logging Unit 2 to $45 \%$ at the base.
The adnVISION tool collected oriented images of bulk density and borehole radius. Despite its limited azimuthal resolution (image data are sampled in 16 azimuthal sectors, i.e., every $22.5^{\circ}$ ), the images display well-defined vertical bands of large borehole radius in the interval 110-438 mbsf, interpreted as borehole breakouts caused by differences in the principal horizontal stresses. The average azimuth of the breakouts is roughly northeast-southwest to eastnortheast-west-southwest, indicating that the maximum horizontal stress is oriented northwest-southeast to north-northwest-south-southeast.

\section{Site U1379}

Site U1379 was drilled in the upper slope of the Costa Rica margin, $28.2 \mathrm{~km}$ offshore Osa Peninsula and Caño Island along BGR99 Line 7 (Fig. F2). The site is located above the locked portion of the plate boundary according to interplate earthquake relocation and geodetic measurements (S.L. Bilek, pers. comm., 2003; LaFemina et al., 2009). The margin here consists of upper plate basement underlying $\sim 890 \mathrm{~m}$ of slope sediments. The primary purpose of drilling Site U1379 is to determine the nature, composition, and physical properties of the upper plate basement. This site is also designed as a "pilot hole" in preparation for proposed deeper CRISP Program B drilling at this location. Three holes were drilled or cored at Site U1379, penetrating 960, 10.5, and 949 $\mathrm{m}$ into the seafloor. Hole U1379A was dedicated to LWD operations to measure in situ physical properties of the material in the borehole. The hole was drilled with an $8 \frac{1}{2}$ inch drill bit with LWD tools in the BHA. Hole U1379B, drilled with the APC system, was completely dedicated to high-resolution geochemical and microbiology sampling to precisely determine the depth of the SMTZ and the associated microbiological changes. Hole U1379C was designed to retrieve as much sediment and basement core as possible within the specified time window. It was drilled with the APC system to refusal at $91.2 \mathrm{mbsf}$, followed by the XCB system to a refusal depth of 949.0 mbsf. The APCT-3 was deployed six times, and usable data were recovered five times. The Flexit orientation tool was deployed on all APC cores in Hole U1379C, but data were lost from the first 10 cores when a critical computer was turned off during the first tool's deployment, causing the tool to lose synchronization with the computer. All APC holes were cored with nonmagnetic core barrels. Core recovery for Site U1379 was $100.3 \%$ with APC and $84.4 \%$ with XCB. Overall, $804 \mathrm{~m}$ of sediment and $12 \mathrm{~m}$ of basement were retrieved, despite the difficult drilling conditions in the basement. 
Based on lithologic characteristics, the sediments recovered from Hole U1379C are divided, from top to bottom, into five lithostratigraphic units (Fig. F8). Unit I, the relatively thin top unit, consists of medium- to coarse-grained sand with abundant shell fragments. It is worth noting that Unit I observed in this hole is not the same lithostratigraphic unit as Unit I in Hole U1378B. Unit II, 650 m thick, is composed of mainly olive-green clayey silt(stone) and silty clay(stone) with minor layers of sand(stone), sandy silty clay(stone), clay, clayey silt(stone), and tephra. The sediments in this unit are massive and well consolidated; the tephra layers are unlithified. Superimposed on the main background sedimentation of Unit II are three subunits, mainly consisting of consolidated clay, clayey silt with intercalated carbonate and dolomite concretions, and fining- and coarsening-upward decimeter-scale sequences of silty sands and sandstone, respectively. Generally, the deposits of Unit II in this hole are lithostratigraphically similar to the clay-rich deposits of Unit II observed in Hole U1378B. Nonetheless, the difference between the abundance of calcareous concretions or lithified carbonate mud clasts observed at this site compared to Site U1378 is striking. Unit III is $\sim 229 \mathrm{~m}$ thick and consists of fining- and coarsening-upward sequences (decimeter thick) of olive-green silty sands and sandstone. Smear slides indicate that the sandstones are dominated by lithic clasts composed of magmatic rock fragments and feldspar minerals. Chlorite is the most abundant accessory mineral and is followed, in decreasing order of abundance, by volcanic glass, opaque minerals, and amphibole. Trace abundances of calcite, pyroxene, and quartz are present. Tephra layers are sparse in this unit, accumulating mainly in one sequence within the upper part of the unit. Unit IV ( $\sim 2 \mathrm{~m}$ thick) consists of carbonate-cemented medium- to coarse-grained sand with well-rounded, lithic pebble-sized clasts and thick-walled shell shards. Unit $\mathrm{V}$ is $\sim 67 \mathrm{~m}$ thick and is composed of matrix-supported breccia with clasts of limestone, basalt, and mudstone in a fine sandy matrix intercalated with basalt in the upper part (881.75-906.72 mbsf) and a sequence of variably sandy and clayey silt in the lower part (916.40947.52 mbsf). The basalt ranges from aphyric to moderately phyric, containing plagioclase, pyroxene, and olivine phenocrysts and showing minor signs of alteration along veins.

Overall, 53 tephra layers $(2-45 \mathrm{~cm}$ thick) have been identified intercalated in the background sedimentation of the different units, the majority of them below 324 mbsf. Smear slides indicate that most tephras consist of felsic glass shards varying from angular blocky, cuspate, flat, and Y-shaped with nearly no bubbles to highly vesicular, pumiceous textures with commonly elongated bubbles. The transparent glass shards of the felsic tephras are mostly fresh without any signs of alteration until Core 334-U1379C-60X. Below this core, divitrification structures increase with depth within the glass shards, reflecting differing levels of alteration. Grain size ranges from very fine to coarse ash (up to millimeter size). Identified mineral assemblages consist of plagioclase, pyroxene, hornblende, and biotite. Plagioclase is the dominant phase, but some tephras are dominated by amphibole and biotite, which normally occur in the most evolved felsic layers. The few observed dark gray mafic ash layers are predominantly composed of dark to light brown glass shards. Most of the glass shards are blocky and are medium to poorly vesicular and show strong signs of alteration, especially in the deeper part of the hole. The mineral assemblages of the mafic tephras include plagioclase, pyroxene, and spinel. In contrast to felsic tephras, mafic tephras contain more crystals. In general, tephra layers have a sharp basal contact to underlying terrigenous sediment but a gradual transition with overlying ash-bearing terrigenous sediment, and many are normally graded in grain size and well sorted.

The structural characteristics of the cored sediment can be divided into three zones corresponding to the upper and lower part of the sedimentary sequences and to Unit V, respectively. The upper part of the sedimentary sequences and the basement represent zones of gently dipping bedding planes and poor fault populations. Several healed normal faults and layer-parallel faults, likely formed during early stage deformation, were found in the upper part of the sedimentary sequences (lithostratigraphic Unit II). A zone with steep bedding dips and increased fault populations characterizes the lower part of the sedimentary sequences, below 597 mbsf. This part contains at least four fault zones composed of brecciated zones, fracture zones, and weakly deformed zones. The first fault zone (642.1-652.8 mbsf) corresponds to the lowermost section of lithostratigraphic Unit II and to considerably low density and high porosity intervals identified by LWD.

Even though, macroscopically, these sediments seem to be heterogeneous, XRD analytical results indicate little variation in mineralogical composition across the lithostratigraphic units described. XRD spectra indicate that the major mineral components are calcite, anorthite, and quartz, with amphibole, chlorite, pyroxene, olivine, and pyrite accessory minerals. Although very few monocrystalline quartz grains were seen in the smear slides, it may be possible that other silica-rich components (sedimentary and magmatic lithic fragments) produced this signal. 
These findings are generally reflected by physical property data obtained on the cored material (Fig. F8). Bulk density values were determined from both gamma ray attenuation (GRA) measurements on whole cores and mass/volume measurements on discrete samples from the working halves of split cores. In general, values of wet bulk density determined from whole-round GRA measurements and measurements from discrete samples agree well. Wet bulk density increases with depth, increasing more rapidly in the upper section than in the lower section, likely a result of dewatering caused by overburden pressure. Bulk density values in the brecciated basement are $\sim 2.3 \mathrm{~g} / \mathrm{cm}^{3}$. Grain densities determined from discrete samples are relatively homogeneous, ranging between 2.6 and $2.8 \mathrm{~g} / \mathrm{cm}^{3}$. Measured porosities within the sediment section are inversely correlated with bulk density, decreasing with increasing depth. Magnetic susceptibilities are, with two exceptions, low and uniform, indicating an abundance of non-iron-bearing clays and scarcity of magnetic minerals. Basement values of magnetic susceptibility are overall quite low considering absolute values; it is unlikely that this material contributes to any magnetic anomalies. Measured natural gamma ray values are relatively uniform to about Core 334-U1379C$78 \mathrm{X}$, below which they start to decrease, consistent with the observed downward increase of sandy sediment and the increase in grain density. NGR values in the basement are mainly low, consistent with the sandy lithologies described in this interval. $P$-wave velocities show a sharp increase from the sediment coverage into the basement, reflecting the low porosity and high consolidation of the sediment. Thermal conductivity increases with depth and is inversely correlated to porosity. Measured downhole temperatures using the APCT-3 show a relatively linear increase of equilibrium temperatures with depth. Coupling these temperatures with the average bottom water temperature as well as with the measured thermal conductivity results in a least-squares geothermal gradient of $41.6^{\circ} \mathrm{C} / \mathrm{km}$ and a heat flow of 40 $\mathrm{mW} / \mathrm{m}^{2}$, which is consistent with forearc values of heat flow.

Generally, the observations summarized above are consistent with changing depositional conditions in a forearc basin that may range from a near-shore environment to shelf sediment to upper slope sediment (turbidites) interrupted by calcareous mud debris from close fluid-venting areas. The calcareous microfossil community identified in the cored sediment also supports this interpretation.

Shipboard studies of calcareous nannofossils and foraminifers are generally used to further constrain the depositional environment and ages of the cored sed- iment. Calcareous nannofossils provided excellent biostratigraphic control for most of the cored section. All observed microfossils are characteristic of the Pleistocene. Based on nannofossil biostratigraphy, sediment retrieved from the lowest core seems to have been deposited in the lowermost Pleistocene. Thus, the sediment throughout the core would be younger than $2.6 \mathrm{Ma}$, resulting in an average sedimentation rate for the upper ( 566 mbsf) and the middle part (566 722 mbsf) of the section of $\sim 1230$ and $100 \mathrm{~m} / \mathrm{m} . \mathrm{y}$. , respectively. Although the boundaries of planktonic foraminifers could not be established, a few occurring horizons of index species are approximately concordant with nannofossil zonation. The faunal changes observed in the benthic foraminiferal community reflect continuous environmental changes from continental shelf to upper slope (middle bathyal).

Paleomagnetic investigations partially support Pleistocene deposition ages and the high sedimentation rates. Stepwise AF demagnetization was performed on all archive-half sections (to $30 \mathrm{mT}$ ), and discrete samples were taken from the working half. For APC cores, inclination data from neither archive-half sections nor discrete sample measurements show any sign of reversed polarity magnetization. Declination data do not show near- $180^{\circ}$ shifts within each core. Thus, the sediments in the APC cores $(<91.2 \mathrm{mbsf})$ were deposited within the Brunhes period $(<0.78$ $\mathrm{Ma})$.

Paleomagnetic measurements on XCB cores are severely affected by drilling-induced remagnetization and are inconclusive. From the pass-through measurements of archive-half sections, one interval at 701-704 mbsf (Section 334-U1379C-83X-3 through the top part of $83 \mathrm{X}-4$ ) shows dominantly reversed polarity after AF demagnetization. Biostratigraphic Zone NN19 of the early Pleistocene is placed at this interval. Using calcareous nannoplankton zonal schemes of the eastern equatorial Pacific for the lower boundary of Zone NN19 (2.3 Ma), this observed reversed polarity should correlate with Chron C1r.2r (1.185-1.778 Ma). If true, this suggests a rapid sedimentation rate ( $>388 \mathrm{~m} / \mathrm{m} . \mathrm{y}$.).

NRM intensities correlate with magnetic susceptibility data, suggesting some of the downhole susceptibility variation reflects changes in magnetic minerals.

The geochemical trends displayed by the analyzed pore water samples (110 whole rounds), interstitial gas samples (118 sediment plug samples), and void gas samples (74 samples) are also consistent with the different materials cored (e.g. Fig. F8). The upper 50 mbsf at this site reflects typical changes associated with organic carbon cycling. Alkalinity and ammo- 
nium increase from seawater values to maxima at 12 mbsf, reflecting organic matter diagenesis. At $\sim 14$ mbsf, the sulfate gradient decreases, associated with a concomitant decrease in ammonium concentrations and decrease in the alkalinity gradient. Based on the sulfate data, the depth of the SMTZ is estimated to be $\sim 30 \mathrm{mbsf}$. This zone is characterized by a decrease in dissolved $\mathrm{Ca}$, suggesting authigenic carbonate precipitation between 20 and 30 mbsf. Below the SMTZ, methane increases with depth and reach the highest concentrations from 42.31 to 67.18 mbsf. The methane at these depths is dominated by microbial production, as indicated by the high ratio of methane to heavier homologues (ethane and propane), with $\mathrm{C}_{1} /\left(\mathrm{C}_{2}+\mathrm{C}_{3}\right)$ values of $\sim 8,000$ to 10,000 .

The pore fluid geochemistry below the zone of most intense biogeochemical cycling can be divided into three zones. The first zone extends from $\sim 50$ to 500 mbsf and is characterized by a steady increase in $\mathrm{Ca}$ concentrations and a decrease in $\mathrm{Mg}$ and $\mathrm{K}$ concentrations with depth. Below $\sim 100$ mbsf, ethane concentrations increase progressively, whereas propane to pentane are only detected in insignificant amounts. At $\sim 360$ mbsf, abrupt increases in $\mathrm{C}_{2}-\mathrm{C}_{5}$ gas concentrations correlate with an increase in ammonium concentrations observed in the pore fluids. Another peak in the heavier hydrocarbon gases occurs at $440 \mathrm{mbsf}$, and $\mathrm{C}_{2}-\mathrm{C}_{5}$ maxima indicate the presence of thermogenic gases at and below 360 mbsf.

The second zone occurs between $\sim 500$ and 800 mbsf and is characterized by a broad zone of low salinity, $\mathrm{Cl}, \mathrm{Ca}, \mathrm{Mg}, \mathrm{NH}_{4}$, and alkalinity concentrations. The $\mathrm{K}$ concentration-depth profile, however, shows a steady decrease in this interval, which is similar to the gradient observed in the upper $500 \mathrm{~m}$ of the sediment section. The lowest $\mathrm{C}_{1} /\left(\mathrm{C}_{2}+\mathrm{C}_{3}\right)$ values observed at this site occur in the zone between 598.49 and $656.55 \mathrm{mbsf}$, in which methane concentrations are between $\sim 3000$ and 6000 ppmv. A strong peak in $\mathrm{C}_{3}-\mathrm{C}_{5}$ concentrations occurs at $\sim 650 \mathrm{mbsf}$, coincident with the minima in $\mathrm{Ca}$ and salinity concentrations observed in the pore fluids. The broad decrease in the major elements and decrease in the ratio of methane to the heavier hydrocarbons correlates with lithostratigraphic Unit III, which is dominated by coarser grained sediment as well as several fault zones identified below $\sim 600$ mbsf. Generally, the inorganic and organic geochemical data suggest lateral and upward flow of a freshened fluid with elevated concentrations of thermogenic hydrocarbons (up to iso-pentanes) and $\mathrm{K}$. The geothermal gradient at Site $\mathrm{U} 1379$ is $40^{\circ} \mathrm{C} / \mathrm{km}$; thus, the temperature between 600 and $800 \mathrm{mbsf}$ ranges from $24^{\circ}$ to $32^{\circ} \mathrm{C}$. This temperature range is too low for in situ production of thermogenic hydrocarbons or for extensive clay dehydration, suggesting the fluid sampled in Unit III is from a deeper source and is migrating laterally and upward along the permeable sand horizons and faults.

The third zone occurs from $\sim 800$ to $\sim 900 \mathrm{mbsf}$ (lithostratigraphic Unit III into Unit IV) and is characterized by a strong linear increase in Ca concentrations and a decrease in $\mathrm{Mg}$ concentrations. These trends suggest that the basement fluid is dominated by fluid-rock reaction with basalt in the basement. Pore fluids are also enriched in hydrocarbon gases in this interval, with methane concentrations ranging from $\sim 1,000$ to $>10,000 \mathrm{ppmv}$ and $\mathrm{CH}_{4} /\left(\mathrm{C}_{2} \mathrm{H}_{6}+\mathrm{C}_{3} \mathrm{H}_{8}\right)$ ratios increasing from $\sim 300$ to 1400 at 800-947.22 centimeters below seafloor.

Results from LWD generally correspond to the observations as well as to the physical property data obtained from the cored sediment. The LWD tools deployed in the hole included the adnVISION 675 (density, neutron, and ultrasonic caliper), the TeleScope 675 (MWD; power and data transmission and drilling parameters), the arcVISION 675 (propagation resistivity, gamma radiation, and annular pressure), and the geoVISION 675 (resistivity images and gamma radiation). The measurements recorded by the LWD tools were downloaded and processed successfully, except for the geoVISION data. The Schlumberger logging engineers and the Schlumberger LWD data processing center in Houston, Texas (USA, were unable to recover useful geoVISION measurements.

Based on the LWD measurements, four logging units have been defined. Logging Unit 1 (0-492 mbsf) corresponds to a compacting sequence where density and resistivity increase and porosity decreases with depth, reaching nearly constant values of $\sim 1.9 \mathrm{~g} / \mathrm{cm}^{3}, 1 \Omega \mathrm{m}$, and $45 \%$ porosity at the base of the unit. The top of logging Unit 2 (492-600 mbsf) is marked by a small step increase in density and resistivity $\left(\sim 2 \mathrm{~g} / \mathrm{cm}^{3}\right.$ and $\left.1.3 \Omega \mathrm{m}\right)$. The distinguishing feature of logging Unit 3 (600-892 mbsf) is the presence of many borehole enlargements, which likely correspond to intervals containing unconsolidated sands or fractured intervals. Logging Unit 4 (892-955 mbsf) corresponds to the basement rocks of the sedimentary sequence and is clearly identified by a sharp shift in the baseline of NGR, density, and resistivity logs. Compared to the sediment above, the basement unit shows a markedly higher average density and resistivity $\left(2.3 \mathrm{~g} / \mathrm{cm}^{3}\right.$ and $\left.2.5 \Omega \mathrm{m}\right)$ and lower porosity ( 20\%).

The adnVISION tool collected oriented images of bulk density and borehole radius. Despite its limited azimuthal resolution (image data are sampled in 16 
azimuthal sectors, i.e., every $22.5^{\circ}$ ), the images clearly display vertical bands of large borehole radius in the interval 292-885 mbsf interpreted as borehole breakouts caused by differences in the principal horizontal stresses. The average azimuth of the breakouts is roughly north-south to north-northwest-southsoutheast, indicating that the maximum horizontal stress is oriented east-west to east-northeast-westsouthwest.

\section{Site U1380}

Site U1380 was drilled as the alternate site for Site U1378 with the objective to core enough sediment to stratigraphically correlate Sites U1378 and U1380 and to core as much basement in the remaining time window as possible. Site U1380 is on the middle slope of the Costa Rica margin above the unlocked portion of the plate boundary as defined by interplate earthquake relocation and geodetic measurements (Fig. F2). The margin here consists of upper plate basement underlying $\sim 550 \mathrm{~m}$ thick slope sediments. The site was drilled to $397 \mathrm{mbsf}$, followed by coring to total depth at $\sim 480 \mathrm{mbsf}$, where Hole U1380A was deteriorating, making it necessary to terminate, plug, and abandon the hole. Overall, we retrieved $52.37 \mathrm{~m}$ of sediment at this site.

Generally, the sediments cored in Hole U1380A were assigned to a single lithostratigraphic unit consisting of olive-green, terrigenous, well-consolidated clayey silt(stone) and silty clay(stone) with minor layers of sand(stone), sandy silty clay(stone), clay, and clayey silt(stone) (Fig. F9). Intercalated in the main background sedimentation are decimeter-scale finingand coarsening-upward sequences of sands as well as several tephra layers. The tephra layers range in thickness from 0.5 to $35 \mathrm{~cm}$. Unconformable and/or inclined bedding of the tephra was observed throughout the entire cored material. In general, the tephra layers have a sharp basal sediment contact and a gradational top contact, mainly normally graded and well sorted. The tephra layers are mainly composed of felsic (>90 vol\%), transparent, colorless, and very fine to coarse ash-sized glass shards with angular blocky, cuspate, flat, or Y-shaped morphology. The majority of the glass is altered, as shown by the undulous extinction under cross-polarized light. In the coarser sand layers, rip-up clasts, rounded clay lenses, and abundant shell fragments are commonly observed. Framboidal pyrite was observed in many of the smear slides throughout lithostratigraphic Unit I.

Structurally, the material cored at Site U1380 is characterized by shallow- to moderate-dipping bedding planes $\left(\right.$ mean $=\sim 40^{\circ}$ ) and two fault zones. The fault zones encountered between 407-419 and 454-477 mbsf show relatively intense fracturing and brecciation.

The physical property data obtained from the cored material display expected behavior with depth and reflect that only a single sediment unit, as well as a limited depth interval, was cored at this site (Fig. F9). Wet bulk densities determined from whole-round GRA measurements are relatively constant throughout the cored interval, with a mean density value of $1.87 \pm 0.05 \mathrm{~g} / \mathrm{cm}^{3}$. Grain densities determined by mass/volume measurements on discrete samples are also relatively constant with depth, with an average value of $2.67 \pm 0.08 \mathrm{~g} / \mathrm{cm}^{3}$; however, the variability increases with depth. These values suggest a terrigenous origin of the deposited material. Porosities obtained by mass/volume measurements on discrete samples using moisture and density (MAD) method $\mathrm{C}$ are also relatively constant through the cored interval, with a value of $49 \%$. The magnetic susceptibility measured in the sedimentary sequence is also relatively homogeneous and low, indicating an abundance of non-iron-bearing clays and scarcity of magnetic minerals. The thermal conductivity is relatively constant throughout the cored interval, with a mean of $1.05 \pm 0.22 \mathrm{~W} /(\mathrm{m} \cdot \mathrm{K})$.

The biogenic components observed at this site are similar to those observed in lithostratigraphic Unit II at Site U1378. Biogenic components have a bimodal distribution in Unit I: shell fragments, diatoms, and nannofossils are sparse but ubiquitous throughout the unit, whereas foraminifers are partly enriched within the sediment and are a major constituent of the sand-sized fraction. Preservation ranges from poor to moderate. Based on nannofossil biostratigraphy (Zone NN19) the sediment retrieved from the basal core was deposited in the early Pleistocene; thus, the sediments cored at Site U1380 are younger than 2 Ma. However, the top and bottom boundaries of Zone NN19, defined by the LOs of P. lacunosa and $D$. brouweri, respectively, could not be constrained. The dominant species observed at this site include $H$. carteri, H. sellii, Helicosphaera neogranulata/hyalina, Coccolithus pelagicus, and C. leptoporus.

Planktonic foraminiferal zones could not be established in the sediment cored at this site because of their rare occurrences. Benthic foraminifers, on the other hand, reflect continuous paleoenvironmental changes. Planktonic foraminifers were observed in limited horizons of six core catcher samples and are characteristic of tropical fauna (G. quadrilobatus $[G$. sacculifer], G. ruber, O. universa, G. menardii, and N. dutertrei). The benthic foraminifers observed at this site are similar to modern assemblages, which is 
characteristic for the oxygen-minimum zone in this region. Thus, benthic foraminiferal faunas mainly represent bathyal species. The faunas include many species similar to those of nearby Site U1378. In general, the following species have been observed: Bolivina argentea, Epistominella smithi, Uvigerina peregrina, Cibicidoides mckannai, and Gyroidina. These species are characteristic of upper to middle bathyal paleoenvironments.

Paleomagnetic investigation revealed behavior similar to that of Site U1378. Stepwise AF demagnetization was performed on all archive-half sections (to $15 \mathrm{mT})$, and discrete samples were taken from the working half. The sections and samples are severely affected by drilling-induced remagnetization, and NRM intensities are comparable to those of Site U1378. The number of discrete samples analyzed so far is too limited to confidently define the magnetic polarity for this site. Thermal demagnetization experiments on three discrete samples revealed low unblocking temperature of NRM $\left(\sim 60 \%\right.$ loss by $\left.100^{\circ} \mathrm{C}\right)$, suggesting that the main NRM carriers are Ti-rich titanomagnetite, maghemite, or goethite.

The geochemical trends displayed by the analyzed pore water and gas samples (10 whole rounds, 9 headspace samples, and 8 void gas samples) mainly follow the same general trend with depth as the fluids observed at Site U1378 (Fig. F9). Salinity, Cl, and Na concentrations show a monotonic decrease with depth. This indicates diffusional communication with fluids at depth. The low chloride concentrations $(380 \mathrm{mM})$ and low salinity $(20 \mathrm{mM}), \sim 60 \%-67 \%$ of seawater, reflect significant freshening of the fluid. Methane $\left(\mathrm{CH}_{4}\right)$ concentrations range between 3,346.67 and 11,925.59 ppmv in interstitial waters from sediment sampled between 398.1 and $475.1 \mathrm{mbsf}$ in Hole U1380A. The gas at these depths is thermogenic in origin, as indicated by the low ratios of methane to heavier homologues (ethane and propane), with $\mathrm{CH}_{4} /\left(\mathrm{C}_{2} \mathrm{H}_{6}+\mathrm{C}_{3} \mathrm{H}_{8}\right)$ values from 458.78 to 551.80 . The $\mathrm{C}_{2} \mathrm{H}_{6}$ concentrations range between 3.89 and 15.69 ppmv, with the highest concentration at $475.1 \mathrm{mbsf}$. Propane is also present in the cores, with concentrations ranging from 1.39 to 7.33 ppmv at depth. Iso- and $n$-butane were detected from 398.1 to $475.1 \mathrm{mbsf}$, with concentrations between 0.55 and 3.45 ppmv. Iso-pentane concentrations ranged from 0.64 to 2.34 ppmv. Propane, butane, and pentane concentrations were all highest at $475.1 \mathrm{mbsf}$.

A clear offset in the $\mathrm{Ca}, \mathrm{Mg}, \mathrm{K}$, ammonium, and alkalinity profiles occurs from $\sim 400$ to 500 mbsf between Sites U1380 and U1378. Ca and ammonium concentrations at Site U1380 are lower than at Site U1378, whereas $\mathrm{K}, \mathrm{Mg}$, and alkalinity concentrations are higher at Site U1380. The $\mathrm{Ca}, \mathrm{Mg}$, and K concentrations were determined twice by inductively coupled plasma-atomic emission spectroscopy at both Sites U1380 and U1378, and the ammonium and alkalinity concentrations were determined by different methods; thus, the offset is not an analytical artifact. Site U1380 is $\sim 1 \mathrm{~km}$ northeast of Site U1378, and the lithostratigraphy at Site U1378 is only partially represented at Site U1380. The interval between $\sim 400$ and 500 mbsf at Site U1378 contains more and thicker sections of coarser grained sediment than at Site U1380, indicating that these horizons are either not present at Site U1380 or were not recovered and sampled. It is likely that these coarser grained horizons are the conduits for the laterally migrating fluids observed at Site U1378, which may explain why the geochemical profiles at Site U1380 show a steady increase ( $\mathrm{Ca}$ and ammonium) or decrease ( $\mathrm{Mg}$ and $\mathrm{K}$ ) through the cored depth and do not display the marked anomalies observed at Site U1378.

\section{Site U1381}

One of the primary objectives of Expedition 334 was to determine the characteristics of the downward-moving plate entering the Costa Rica Subduction Zone. Fundamental to this objective is an understanding of the nature and hydrologic system of the igneous section entering the zone. In this context Site U1381 serves as a reference site. Site U1381 is also situated on BGR99 Line 7, offshore Osa Peninsula and Caño Island. Site U1381 is on a basement-relative high at common midpoint 5750 $\left(8^{\circ} 25.7150^{\prime} \mathrm{N}, 84^{\circ} 9.4690^{\prime} \mathrm{W}\right)$ at $2067 \mathrm{~m}$ below sea level (Fig. F2). The fundamental difference between this site and the other sites drilled during this expedition is that it is situated on the incoming Cocos Plate outboard of the Middle America Trench. The seismic reflection profile indicates that the basement sediment cover is $\sim 120 \mathrm{~m}$ thick at this site and that it most likely consists of pelagic and hemipelagic sediment. This section disconformably overlies highly reflective basement interpreted as the igneous crust of the Cocos Ridge. Two holes were drilled at this site, Holes U1381A and U1381B. Hole U1381A was drilled to recover as much of the sediment cover and basement rock as possible in the specified time window. Hole U1381B was drilled to retrieve the uppermost $30 \mathrm{~m}$ of sediment for detailed geochemical sampling and to take five in situ temperature measurements to determine the geothermal gradient and heat flux at this site. Overall, $54.15 \mathrm{~m}$ of sediment and $35.69 \mathrm{~m}$ of basement were retrieved at this site, with average recovery rates of $42.30 \%$ and $54.82 \%$, respectively.

The material cored in Hole U1381A can be divided into eight lithostratigraphic units (Fig. F10). Unit I, $\sim 46.14 \mathrm{~m}$ thick, consists mainly of light greenish gray 
soft clay sediment with minor layers of silty clay and three tephra layers, ranging in thickness from 2 to 4 $\mathrm{cm}$. In general, Unit I is massive with minor changes in the proportions of clay and silt. Biogenic components, especially nannofossils and diatoms, are abundant throughout the unit. Foraminifers, spicules, and radiolarians are present in trace abundances. Smear slide investigations show that the main accessory components observed in this unit are silt-sized grains of feldspar, chert, chlorite, pyroxene, amphibole, opaque minerals, calcite, glauconite, fragments of radiolarians, foraminifers, sponge spicules, glass, and rare quartz. Unit II is $\sim 49.64 \mathrm{~m}$ thick and consists of mainly dark grayish to yellowish brown soft to hardened clay/(stone) with abundant intercalated tephra layers. The base of the sediment cover is partly silicified. Unit II is clearly distinguishable from Unit I by its abundant biogenic components and by an abrupt color change. Unit II sediment is $>70 \%$ spicules, diatoms, radiolarians, and nannofossils. The dominantly felsic tephra layers range in thickness from 0.5 to 35 $\mathrm{cm}$, are massive to soft, show normal gradation, and are well sorted. One notable exception is a $35 \mathrm{~cm}$ thick silicified mafic tephra layer in interval 334U1381A-7R-1, $92 \mathrm{~cm}$, through 7R-2, $9 \mathrm{~cm}$, that shows parallel and cross lamination. With the exception of one tephra layer (interval 5R-5, 29-34 cm), all other tephras show devitrification structures within the glass shards and severe signs of alteration. Grain size ranges from very fine to coarse ash (up to millimeter size). The mineral assemblages observed in the tephra layers consist of plagioclase, pyroxene (hypersthene and augite), hornblende, and biotite. Bedding dips, identified at compositional boundaries or grain-size differences, of the entire cover sediment sequence are almost horizontal (mostly $\leq 5^{\circ}$ ). The igneous rocks cored at Site U1381 (Unit III) consist of aphyric to highly plagioclase phyric and sometimes even glomerophyric pillow basalt sometimes separated by fresh to altered chilled margins (Unit III). Phenocrysts are distributed in a microcrystalline to fine- or mediumgrained matrix consisting of plagioclase and pyroxene. Vesicularity is usually high (up to $20 \%$ ), however, the irregular to spherical shaped vesicles are commonly filled with authigenic minerals. This unit was cored until TD.

Structures of the sedimentary sequence cored at this site are characterized by gently dipping (mostly $\leq 5^{\circ}$ ) bedding planes, whereas structures of the cored basalt are characterized by fractures with varying dipping angles of $19^{\circ}-86^{\circ}$ partly filled with vein minerals. No brittle deformation such as faults and fractures was recognized in the sediment cores.
The physical property data obtained from the cored material are variable, which is consistent with the different lithologies cored at this site (Fig. F10). Wet bulk densities determined from whole-round GRA measurements are relatively constant throughout the cored sediment section at this site, with a mean density value of $1.40 \pm 0.14 \mathrm{~g} / \mathrm{cm}^{3}$. GRA-derived bulk densities of the basement are highly variable because of variable filling of the core liner, with a maximum value of $2.3 \mathrm{~g} / \mathrm{cm}^{3}$. Grain densities determined by mass/volume measurements on discrete samples of the cored sediment, although showing a large scatter, generally decrease with depth from $\sim 2.7$ to $2.5 \mathrm{~g} / \mathrm{cm}^{3}$. Porosities obtained by mass/volume measurements on discrete samples using MAD method C are relatively constant through the cored sediment interval at $76 \%$. Generally, porosity is expected to decrease with depth; the observed constant values could be an artifact caused by the RCB coring system. The magnetic susceptibility measured in the sedimentary sequence is low, with a mean value of $0.009 \pm 0.016$ SI. The magnetic susceptibility measured in the basement rocks is generally higher, increasing from the sediment/basement interface to 140 mbsf, followed by a slow decrease toward the bottom of the hole. The thermal conductivity is relatively constant throughout the cored interval, with a mean of $0.79 \pm 0.08$ and $1.45 \pm 0.07 \mathrm{~W} /(\mathrm{m} \cdot \mathrm{K})$ in sediment and basement, respectively. These values are quite low for basalt and might be an artifact of the samples not being water saturated before measurement because of time constraints. Downhole equilibrium temperatures acquired using the SET increase linearly with depth and give a least-squares geothermal gradient, coupled with the average bottom water temperature, of $222^{\circ} \mathrm{C} / \mathrm{km}$. The heat flow calculated using the mean thermal conductivity of $0.8 \mathrm{~W} /(\mathrm{m} \cdot \mathrm{K})$ is $178 \mathrm{~mW} / \mathrm{m}^{2}$. This value is significantly larger than the half-space prediction for $15 \mathrm{Ma}$ crust $\left(130 \mathrm{~mW} / \mathrm{m}^{2}\right)$ and larger than the observed global average heat flow for crust of this age $\left(77 \mathrm{~mW} / \mathrm{m}^{2}\right.$ ) (Stein and Stein, 1992). This high heat flow value is an indicator for significant fluid flow within the underlying crust.

The nannofossil and foraminiferal community observed at this site provide significant biostratigraphic control of the cored sediment sequence above the basaltic basement of the Cocos Ridge and reflect the sedimentological differences described above. Based on microfossil biostratigraphy, the sedimentary layers are tentatively divided into an upper part of Pleistocene age and a lower part of middle Miocene age. Thus, the sediment just above the basement is tenta- 
tively estimated to be of middle Miocene age. The sediment just above basement basalt would be younger than $16 \mathrm{Ma}$. The zonation of planktonic foraminifers is approximately concordant with that of the calcareous nannofossils.

Two different environments, based on species, abundance, and preservation, are represented in the cored sediment at Site U1381. The upper interval (3.69$49.62 \mathrm{mbsf}$ ) represents a hemipelagic environment mixed with terrigenous material, whereas the lower interval (53.86-95.5 mbsf), a silicic to calcareous ooze, represents a pelagic environment. The nannofossil assemblage observed in the upper $31.9 \mathrm{mbsf}$ is characteristic of lower Pleistocene Zones NN20NN19 and contains G. oceanica, G. caribbeanica, $H$. carteri, and C. leptoporus. However, because of poor preservation and the lack of zonal markers, this interval cannot be biostratigraphically zoned. The interval to 41.5 mbsf is tentatively assigned to nannofossil Zone NN19 based on the occurrence of $P$. lacunosa and the absence of $D$. brouweri. However, the top boundary, defined by the LO of P. lacunosa, is undetermined. Sample 334-U1381A-6R-CC (49.62 mbsf) contains a diverse nannofossil assemblage of mixed ages ranging from the Pleistocene Zone NN19 into the upper to middle Miocene. This diverse assemblage is dominated by Pleistocene species, including G. oceanica, G. caribbeanica, H. carteri, and C. leptoporus. Also present, but rare to few in abundance, are Miocene species including Discoaster bellus, Discoaster exilis, Discoaster quinqueramus, Discoaster variabilis, and unidentifiable five- and sixrayed discoasters. The discoasters are poorly to moderately preserved, whereas the placoliths exhibit moderate to good preservation. The condition of the discoasters and the rarity or lack of biostratigraphic markers prevents the further delineation of the Pliocene and Miocene zones.

The lower interval between 53.86 and $95.5 \mathrm{mbsf}$ is assigned to middle Miocene Zone NN5 based on the occurrence of Helicosphaera heteromorphus and the absence of Helicosphaera ampliaperta. The top and bottom of this zone cannot be constrained because of the uncertainty of the LOs of biostratigraphic markers. Typical species found in the samples include Sphenolithus heteromorphus, Sphenolithus moriformis, C. leptoporus, Cyclicargolithus floridanus, Coccolithus miopelagicus, D. exilis, D. variabilis, Discoaster deflandrei, and Reticulofenestra pseudoumbilicus.

Planktonic foraminifers were analyzed in nine core catcher samples. Foraminifers are abundant to common in the sediment of Hole U1381A. Preservation is good to moderate. Fragmentation of foraminifers caused by carbonate dissolution is observed in the samples of sediment from lower bathyal depths.
Planktonic foraminifers, abundant to common in this hole, are much more abundant than benthic foraminifers. These trends are quite different from the trends observed in the cored sediment of the other sites. Similar to the observed nannofossil communities in this hole, the foraminiferal assemblages of the upper part of the sediment sequence are quite different from those of the lower parts. This is either caused by a hiatus or by very low sedimentation rates. The foraminiferal community of the upper sediment sequence (3.69-49.62 mbsf) is characterized by tropical fauna (G. quadrilobatus [G. sacculifer], G. ruber, O. universa, G. menardii, and N. dutertrei). Sample 334-U1381A-3R-CC (13.34 mbsf) contains G. ruber (pink) and is assigned to the Pleistocene (older than $0.12 \mathrm{Ma}$ ). Sample 6R-CC (49.64 mbsf) contains sinistral coiling Pulletiatina and is assigned to be older than $0.8 \mathrm{Ma}$ but younger than $4 \mathrm{Ma}$. From 53.86 to $95.55 \mathrm{mbsf}$, planktonic foraminiferal assemblages are composed of Dentoglobigerina altispira, $G$. quadrilobatus, Globigerinoides obliquus, Globoquadrina dehiscens, Globorotalia peripheronda, Globorotalia peripheroacuta, Paragloborotalia siakensis, and Orbulina suturalis. This sequence is tentatively assigned to planktonic foraminiferal Zone M7 (14 Ma). However, the occurrence of Praeorbulina circularis at $\sim 95.55$ mbsf may be a sign that the sediment just above the basement basalt is much older (either Zone M5 or M6).

Paleomagnetic experiments with stepwise AF demagnetization were performed on all archive-half sections and discrete samples taken from the working half. Archive-half sections were demagnetized to 15 $\mathrm{mT}$ for the sediment and $10 \mathrm{mT}$ for the basalt. For the sediment, NRM intensity is too weak for the shipboard experiments to determine characteristic remanent magnetization (ChRM). For the basalt, the majority of the measured samples revealed a ChRM with shallow and positive inclination. Several intervals reveal a NRM with negative inclinations, possibly reflecting prolonged igneous activity.

The NRM intensity of the basalt ranges from 1 to 8 $\mathrm{A} / \mathrm{m}$. The samples from the top of the basalt section (Cores 334-U1381A-12R through 16R) frequently show NRM with shallow inclination, consistent with the low latitude, and strong intensity. The samples below Core 16R show NRM with steeper inclination of $\sim 50^{\circ}$, indicating a stronger effect from drillinginduced remagnetization, and lower intensities. Thermal demagnetization experiments on three discrete samples revealed that blocking temperature of $\mathrm{NRM}$ is $550^{\circ}-580^{\circ} \mathrm{C}$, suggesting that the main NRM carrier is titanomagnetite with a low Ti content.

The geochemical trends displayed by the analyzed pore water samples (17 whole rounds) are generally 
controlled by organic carbon cycling, alteration of volcanic ash, and diffusive exchange with basement. Salinity is lower than seawater value between 13 and 24 mbsf but increases gradually below this depth to the base of the sediment column (Fig. F10). Chloride concentrations are slightly below modern seawater value. A similar dilution of $\mathrm{Cl}$ concentrations of $2.5 \%$ lower than modern seawater was observed in the upper $100 \mathrm{~m}$ of the sediment column cored at the reference site (ODP Site 1039) offshore the Nicoya Peninsula (Kimura, Silver, Blum, et al., 1997). Sodium concentrations are below seawater value throughout the cored section and reach a minimum at 35 mbsf. Sodium concentrations are relatively constant below this depth. Sulfate concentrations decrease to a minimum at 23 mbsf and increase nearly linearly with depth. The alkalinity concentration-depth profile is a mirror image of the sulfate profile, reaching a maximum at 23 mbsf and decreasing toward the base of this hole. Organic matter diagenesis in the upper part of the sediment section is also observed in the ammonium profile, which reaches a maximum value at 23 mbsf. Ammonium concentrations remain nearly constant to $35 \mathrm{mbsf}$ and decrease nearly linearly. Calcium concentrations reach a minimum value just below the sulfate minimum at 23 mbsf, suggesting precipitation of authigenic carbonates in the zone of active sulfate reduction and alkalinity production. Below this depth, calcium concentrations monotonically increase toward the base of the sediment column, which most likely reflects diffusive exchange with a basement fluid.

Potassium and $\mathrm{Mg}$ show similar decreases at this depth and exhibit minima at 35 mbsf, which is consistent with the abundant alteration of the volcanic tephra in this interval. Magnesium concentrations remain relatively constant between 45 and $81 \mathrm{mbsf}$ and decrease again at the sediment/basement interface.

\section{Summary and conclusions}

Expedition 334 incorporated both shallow-water drilling on the Caribbean plate continental upper slope (Site U1379) and deepwater drilling on the Cocos plate (Site U1381). This latter site also represented the first ever penetration of the Cocos Ridge igneous basement. A third target area was the Caribbean middle slope, where we drilled Sites U1378 and U1380. Acquisition of LWD logs prior to coring was planned and successfully implemented at Sites U1378 and U1379.

Slope sediments at Sites U1378-U1380 had 100\% recovery. Site U1379 had $20 \%$ recovery in the hard formation forming the basement of the Caribbean plate. Unfortunately, both LWD and coring were interrupted without reaching the upper plate basement at Sites U1378 and U1380 because of deteriorating hole conditions.

Before entering into the scientific facts regarding the cruise, we want to thank the drillers and all JOIDES Resolution staff for their collaboration and optimistic vision of the challenges that they always took with no hesitation. All major objectives of the expedition, both in the view of the entire Costa Rica Seismogenesis Project and as stand-alone goals, were fulfilled, and below we will provide major highlights.

- Estimate the composition, texture, and physical properties of the upper plate material.

The basement was successfully drilled at Site U1379. This site is on the upper slope at $127 \mathrm{~m}$ water depth. At Site U1379, both cores and LWD logs penetrated below the slope sediment and upper plate basement interface for 50 and $70 \mathrm{~m}$, respectively. LWD logs showed a marked increase in density and resistivity at $~ 892$ mbsf. This change in physical properties was interpreted as penetration into the upper plate basement after drilling a continuous section of slope sediment. Indeed, successive coring at Site U1379 showed a complex change in lithostratigraphy, going from sandstones with lithic fragments of igneous origin to bioclastic sandstones to a poorly sorted, well-lithified breccia with sandy matrix and igneous, calcareous, and mudstone clasts to mudstone. It remains unclear if we entered a transition zone with clasts of basement, for example an erosional surface, or the basement itself. The difficulties are due to the fact that the expected basement at Site U1379 was a mélange; the mudstone recovered from the bottom of the hole may or may not be the matrix of the mélange. We need further analysis to completely answer this question.

A second penetration of the basement was attempted at Site U1378. Neither LWD logs nor coring were successful in reaching the basement at this site. Hole conditions did not allow penetration deeper than 457 mbsf during logging and 524 mbsf during coring, whereas the expected depth of top of basement was $\sim 750$ mbsf. Successive core description revealed the presence of highly fractured and brecciated zones interpreted as fault zones, which may have prohibited drilling advance.

A final attempt to reach the basement was conducted at Site U1380, where the basement was expected at $\sim 550$ mbsf. Site U1380 is $\sim 1 \mathrm{~km}$ upslope from Site U1378, but we encountered the same problems, here at $482 \mathrm{mbsf}$.

- Assess subduction channel thickness and the rate of subduction erosion. 
In an erosive subduction margin, the upper plate material is incorporated into the subduction channel because of basal erosion, resulting in subsidence of the upper plate. Estimation of mass removal from the upper plate in the CRISP area based on subsidence profiles of slope sediment is crucial to assess the thickness of the subduction channel. Expedition 334 successfully recovered slope sediment offshore Osa Peninsula where the Cocos Ridge is subducting beneath the Caribbean plate. The preliminary results of biostratigraphic ages obtained from two slope sites indicate high sedimentation rates in the terrestrially sourced slope sequence, ranging from $516-236 \mathrm{~m} / \mathrm{m}$.y. at Site U1378 in the middle slope to $1035-160$ $\mathrm{m} / \mathrm{m}$.y. at Site U1379 in the upper slope. In particular, the sedimentation rate of the slope sediment, mainly composed of clayey silt/silty clay, at Site $\mathrm{U} 1379$ is $1035 \mathrm{~m} / \mathrm{m} . \mathrm{y} .$, much higher than that of slope sediment offshore Nicoya Peninsula (38-99 $\mathrm{m} / \mathrm{m} . \mathrm{y}$.$) (Kimura, Silver, Blum, et al., 1997). The re-$ markably high sedimentation rate offshore Osa Peninsula could be derived from onland uplift triggered by the subduction of the Cocos Ridge. On the other hand, the subduction of such a topographic high likely accelerates the basal erosion of the upper plate. The subsidence/uplift profiles of the slope sediment offshore Osa Peninsula are controlled by the high sedimentation rate and basal erosion; the subsidence of the upper plate likely occurred when the rate of subduction erosion was higher than the slope sedimentation rate. The detailed research of sedimentary facies and benthic foraminifer faunal in slope sediments at Sites U1378 and U1379 are keys to estimate the mass removal associated with basal erosion and the thickness of the subduction channel.

- Evaluate fluid/rock interaction, the hydrologic system, and the geochemical processes (indicated by composition and volume of fluids) active within the upper plate.

Fluid flow and fluid pressure in subduction zones can have a profound impact on the shallow thermal structure and fluid content of the subducting and upper plates; fault zone stability and seismogenesis; and the transfer of elements and isotopes to the ocean, volcanic arc, and mantle. Changes in physical and mineralogical properties with depth and the associated evolution of fluids in subduction zones may be intimately linked to the transition from aseismic to seismic behavior along the plate boundary. Fluids advected along fault zones and other permeable horizons in the upper plate record reactions occurring at greater depths in the subduction zone and can be used to constrain reactions occurring within the seismogenic zone. The shipboard geochemistry program during Expedition 334 identified two zones in the upper plate with fluid compositions indicative of transport of fluids from greater depths and one zone in the reference site where there is lateral flow of modified seawater in the igneous basement.

Pore fluids in the uppermost $\sim 50 \mathrm{~m}$ at all sites drilled during Expedition 334 are dominated by reactions associated with the cycling of organic carbon. Within the uppermost $50 \mathrm{~m}$, active sulfate reduction, biogenic methane production, and precipitation of authigenic carbonates are present. The depth of the sulfate-methane transition (SMT) varies from site to site, with the shallowest SMT occurring at 13 mbsf at Site U1378. The sulfate reduction profile at Site U1379 has a steep gradient to $15 \mathrm{mbsf}$ and then becomes less steep, reaching depletion at $\sim 30$ mbsf. The change in the gradient at the slope site (U1379) may reflect changes in the type of organic matter in the sediment or a change in sedimentation rates. At Site U1381, the diffusive flux of sulfate from the overlying water column and from the basement aquifer below the sediment section is faster than microbial sulfate reduction rates in the sediment column; thus, sulfate does not reach depletion in the reference site.

Fluid flow was detected at each of the sites cored. The flow at each site overprints the general geochemical profiles that are influenced by in situ diagenetic reactions such as ion exchange, ongoing microbial metabolic reactions, volcanic ash alteration, and carbonate precipitation/dissolution. At Site U1379, a broad zone from $\sim 600$ to 800 mbsf contains a fluid with low $\mathrm{Cl}$ concentrations and peaks in concentrations of thermogenic hydrocarbons (ethane, propane, $n$-butane, and iso-butane). The geothermal gradient at Site U1379 is too low to support the in situ production of thermogenic hydrocarbons or for extensive clay dehydration, suggesting a deeper source for the fluid and migration along the permeable sand horizons and fault zones within this depth interval. At Site U1378, there is a monotonic decrease in $\mathrm{Cl}, \mathrm{Mg}$, and $\mathrm{K}$ concentrations and increase in $\mathrm{Ca}$ concentration with depth, suggesting diffusional communication with fluids below the base of the hole. It is likely that this fluid resides in the fault zone in the basement imaged in the seismic reflection profiles at this site. The fluid at the base of the hole is more dilute (altered) than the fluids sampled at Site U1379. The ratio of methane to the thermogenic hydrocarbons also decreases with depth at this site. The in situ temperature at the sediment/basement contact is too low to support in situ clay dehydration or thermogenic hydrocarbon formation; thus, this fluid must also be transported from greater 
depths. At Site U1381, the geochemical profiles below $\sim 50$ mbsf reflect diffusional communication with a fluid with seawater-like chemistry in the igneous basement.

- Measure the stress field along the CRISP transect.

We estimated present-day in situ stress orientation from borehole breakouts at Site U1378 in the middle slope and Site U1379 in the upper slope. Borehole breakouts in a vertical hole form in a direction perpendicular to the maximum horizontal principal stress $\left(\sigma_{\mathrm{Hmax}}\right)$ (Zoback et al., 2003). During Expedition 334, borehole breakouts were identified from LWD images of borehole radius and density. In addition, we determined types, orientations, and kinematics of faults from cores.

Breakout orientation of slope sediment at Site U1378 indicates that $\sigma_{H \max }$ is oriented north-northwestsouth-southeast. Both normal and reverse faults are observed in cores from slope sediment at Site U1378. The $\sigma_{H \max }$ orientation at Site U1378 is consistent with the north-northwest-directed plate motion vector detected by GPS measurement northwest of Osa Peninsula (LaFemina et al., 2009) and is oblique to the convergence direction (north-northeast) between the Cocos and Caribbean plates (DeMets, 2001). The Cocos Ridge is considered to act as a rigid indenter to the Caribbean plate, resulting in change in plate motion from north-northeast-directed trench-normal motion in southern Costa Rica to trench-parallel motion in central Costa Rica where plate convergence is normal to the trench (LaFemina et al., 2009). North-northwest-oriented $\sigma_{H \max }$ at Site U1378 may represent shortening of the middle slope opposite the northwestern flank of the Cocos Ridge (thrust faulting stress regime) where plate motion likely deviates from trench-normal motion, although strike-slip and/or normal stress states are also possible.

The $\sigma_{H \max }$ orientation of slope sediment at Site U1379 is east-northeast-west-southwest, perpendicular to $\sigma_{H \max }$ orientation at Site U1378. No obvious borehole breakouts appear in the underlying basement at Site U1379. Normal faults dominate in cores from slope sediment at Site U1379. Kinematic analyses of normal faults indicate a vertical maximum principal stress $\left(\sigma_{1}\right)$, an intermediate principal stress $\left(\sigma_{2}\right)$ oriented west-northwest, and a minimum principal stress $\left(\sigma_{3}\right)$ oriented north-northeast. The $\sigma_{\text {Hmax }}$ orientation at Site U1379 is consistent with north-northwest-directed horizontal extension parallel to the plate motion vector detected by GPS measurement northwest of Osa Peninsula (LaFemina et al., 2009) and thus appears to represent a present stress state. On the other hand, the $\sigma_{3}$ orientation determined from kinematic analyses of core-scale normal faults is parallel to the convergence direction between the Cocos and Caribbean plates (DeMets, 2001). Core-scale normal faults record instantaneous stress conditions when the faults are active. Although stress data sets are derived from slope sediment overlying the upper plate basement, trenchnormal extension at Site U1379 is consistent with extensional faulting in the submarine wedge associated with basal erosion (Ranero and von Huene, 2000).

In summary, stress at the middle slope site is compressional, whereas that at the upper slope site is extensional. This marked change in stress state occurs within $\sim 12 \mathrm{~km}$ along the CRISP transect in the northwestern flank of the Cocos Ridge and may correspond to a change from compression (middle slope) to extension (upper slope), marking the onset of subduction erosion between Sites U1378 and U1379.

\section{Cocos Ridge subduction: evolution of the Central America volcanic arc and development of the volcanic arc gap inboard Cocos Ridge}

Expedition 334 is the first research endeavor to drill into the sediment and basalt of Cocos Ridge, which is the trace of the Galapagos hotspot on the Cocos plate. We successfully recovered $\sim 80 \mathrm{~m}$ of Cocos Ridge basalt, underlying $\sim 100 \mathrm{~m}$ of biogenic pelagic sediment, mainly siliceous to calcareous oozes.

Approximately 170 tephra layers were described and sampled from the cored holes at four different sites with ages ranging from middle Miocene to the present. Postcruise analyses of the tephra will shed light on the evolution of the magmatic arc, including the deactivation of the volcanoes located on the presentday location of the Talamanca Cordillera.

\section{References}

Abratis, M., and Wörner, G., 2001. Ridge collision, slabwindow formation, and the flux of Pacific asthenosphere into the Caribbean realm. Geology, 29(2):127130. doi:10.1130/0091-

7613(2001)029<0127:RCSWFA>2.0.CO;2

Aden-Arroyo, I., 2008. Local earthquake tomography at the Central Pacific margin of Costa Rica [Ph.D. thesis]. Kiel, Christian-Albrechts-Univ.

Arroyo, I.G., Husen, S., Flueh, E.R., Gossler, J., Kissling, E., and Alvarado, G.E., 2009. Three-dimensional $P$-wave velocity structure on the shallow part of the Central Costa Rican Pacific margin from local earthquake tomography using off- and onshore networks. Geophys. J. Int., 179(2):827-849. doi:10.1111/j.1365246X.2009.04342.X 
Aubouin, J., von Huene, R., et al., 1982. Init. Repts. DSDP, 67: Washington (U.S. Govt. Printing Office). doi:10.2973/dsdp.proc.67.1982

Barckhausen, U., Ranero, C.R., von Huene, R., Cande, S.C., and Roeser, H.A., 2001. Revised tectonic boundaries in the Cocos plate off Costa Rica: implications for the segmentation of the convergent margin and for plate tectonic models. J. Geophys. Res., [Solid Earth], 106(B9):19207-19220. doi:10.1029/2001JB000238

Barckhausen, U., Roeser, H.A., and von Huene, R., 1998. Magnetic signature of upper plate structures and subducting seamounts at the convergent margin off Costa Rica. J. Geophys. Res., [Solid Earth], 103(B4):7079-7094. doi:10.1029/98JB00163

Bohrmann, G., Heeschen, K., Jung, C., Weinrebe, W., Baranov, B., Cailleau, B., Heath, R., Hühnerbach, V., Hort, M., Masson, D., and Trummer, I., 2002. Widespread fluid expulsion along the seafloor of the Costa Rica convergent margin. Terra Nova, 14(2):69-79. doi:10.1046/j.1365-3121.2002.00400.x

Buchs, D.M., and Baumgartner, P.O., 2003. The Osa-Caño accretionary complex (southern Costa Rica): sedimentary processes in the Middle American Trench recorded in an emerged Eocene-Miocene accretionary prism [10th Meeting of Swiss Sedimentologists (SWISS SED), Fribourg, Switzerland]. (Abstract)

Carr, M.J., 1984. Symmetrical and segmented variation of physical and geochemical characteristics of the Central American Volcanic Front. J. Volcanol. Geotherm. Res., 20(3-4):231-252. doi:10.1016/0377-0273(84)90041-6

Carr, M.J., Feigenson, M.D., and Bennett, E.A., 1990. Incompatible element and isotopic evidence for tectonic control of source mixing and melt extraction along the Central American arc. Contrib. Mineral. Petrol., 105(4):369-380. doi:10.1007/BF00286825

Carr, M.J., Feigenson, M.D., Patino, L.C., and Walker, J.A., 2003. Volcanism and geochemistry in Central America: progress and problems. In Eiler, J. (Ed.), Inside the Subduction Factory. Geophys. Monogr., 138:153-174.

Carr, M.J., Patino, L.C., and Feigenson, M.D., 2007. Petrology and geochemistry of lavas. In Bundschuh, J., and Alvarado, G.E. (Eds.), Central America: Geology, Resources, and Hazards (Vol. 1): London (Taylor and Francis).

Chan, L.-H., and Kastner, M., 2000. Lithium isotopic compositions of pore fluids and sediments in the Costa Rica subduction zone: implications for fluid processes and sediment contribution to the arc volcanoes. Earth Planet. Sci. Lett., 183(1-2):275-290. doi:10.1016/S0012821X(00)00275-2

Corrigan, J., Mann, P., and Ingle, J.C., Jr., 1990. Forearc response to subduction of the Cocos Ridge, PanamaCosta Rica. Geol. Soc. Am. Bull., 102(5):628-652. doi:10.1130/0016-7606(1990)102<0628:FRTSOT>2.3.CO;2

Davis, E.E., and Villinger, H.W., 2006. Transient formation fluid pressures and temperatures in the Costa Rica forearc prism and subducting oceanic basement: CORK monitoring at ODP Sites 1253 and 1255. Earth Planet. Sci. Lett., 245(1-2):232-244. doi:10.1016/ j.epsl.2006.02.042
DeMets, C., 2001. A new estimate for present-day CocosCaribbean plate motion: implications for slip along the Central American Volcanic Arc. Geophys. Res. Lett., 28(21):4043-4046. doi:10.1029/2001GL013518

DeShon, H.R., Schwartz, S.Y., Newman, A.V., González, V., Protti, M., Dorman, L.M., Dixon, T.H., Sampson, D.E., and Flueh, E.R., 2006. Seismogenic zone structure beneath the Nicoya Peninsula, Costa Rica, from threedimensional local earthquake $P$ - and $S$-wave tomography. Geophys. J. Int., 164(1):109-124. doi:10.1111/ j.1365-246X.2005.02809.X

Di Marco, G., Baumgartner, P.O., and Channell, J.E.T., 1995. Late Cretaceous-early Tertiary paleomagnetic data and revised tectonostratigraphic subdivision of Costa Rica and western Panama. In Mann, P. (Ed.), Geologic and Tectonic Development of the Caribbean Plate Boundary in Southern Central America. Spec. Pap.-Geol. Soc. Am., 295:1-27.

Dinc, A.N., Koulakov, I., Thorwart, M., Rabbel, W., Flueh, E.R., Arroyo, I., Taylor, W., and Alvarado, G., 2010. Local earthquake tomography of central Costa Rica: transition from seamount to ridge subduction. Geophys. J. Int., 183(1):286-302. doi:10.1111/j.1365246X.2010.04717.x

Dixon, T.H., 2003. Relations between seismic coupling and mountain building based on GPS observations in Costa Rica. Geophys. Res. Abstr., 5:04374. http:// www.cosis.net/abstracts/EAE03/04374/EAE03-J04374.pdf

Dzierma, Y., Thorwart, M.M., Rabbel, W., Flueh, E.R., Alvarado, G.E., and Mora, M.M., 2010. Imaging crustal structure in south central Costa Rica with receiver functions. Geochem., Geophys., Geosyst., 11(8):Q08S26. doi:10.1029/2009GC002936

Expedition 334 Scientists, 2012a. Site U1378. In Vannucchi, P., Ujiie, K., Stroncik, N., Malinverno, A., and the Expedition 334 Scientists, Proc. IODP, 334: Tokyo (Integrated Ocean Drilling Program Management International, Inc.). doi:10.2204/iodp.proc.334.103.2012

Expedition 334 Scientists, 2012b. Site U1379. In Vannucchi, P., Ujiie, K., Stroncik, N., Malinverno, A., and the Expedition 334 Scientists, Proc. IODP, 334: Tokyo (Integrated Ocean Drilling Program Management International, Inc.). doi:10.2204/iodp.proc.334.104.2012

Expedition 334 Scientists, 2012c. Site U1380. In Vannucchi, P., Ujiie, K., Stroncik, N., Malinverno, A., and the Expedition 334 Scientists, Proc. IODP, 334: Tokyo (Integrated Ocean Drilling Program Management International, Inc.). doi:10.2204/iodp.proc.334.105.2012

Expedition 334 Scientists, 2012d. Site U1381. In Vannucchi, P., Ujiie, K., Stroncik, N., Malinverno, A., and the Expedition 334 Scientists, Proc. IODP, 334: Tokyo (Integrated Ocean Drilling Program Management International, Inc.). doi:10.2204/iodp.proc.334.106.2012

Ehrenborg, J., 1996. A new stratigraphy for the Tertiary volcanic rocks of the Nicaraguan Highland. Geol. Soc. Am. Bull., 108(7):830-842. doi:10.1130/0016-7606(1996)108<0830:ANSFTT $>2.3 . \mathrm{CO} ; 2$ 
Feigenson, M.D., and Carr, M.J., 1986. Positively correlated $\mathrm{Nd}$ and $\mathrm{Sr}$ isotope ratios of lavas from the Central American volcanic front. Geology, 14(1):79-82. doi:10.1130/ 0091-7613(1986) 14<79:PCNASI >2.0.CO;2

Feigenson, M.D., Carr, M.J., Maharaj, S.V., Juliano, S., and Bolge, L.L., 2004. Lead isotope composition of Central American volcanoes: influence of the Galapagos plume. Geochem., Geophys., Geosyst., 5(6):Q06001. doi:10.1029/ 2003GC000621

Fisher, A.T., Stein, C.A., Harris, R.N., Wang, K., Silver, E.A., Pfender, M., Hutnak, M., Cherkaoui, A., Bodzin, R., and Villinger, H., 2003. Abrupt thermal transition reveals hydrothermal boundary and role of seamounts within the Cocos plate. Geophys. Res. Lett., 30(11):1550-1553. doi:10.1029/2002GL016766

Fisher, D.M., Gardner, T.W., Sak, P.B., Sanchez, J.D., Murphy, K., and Vannucchi, P., 2004. Active thrusting in the inner forearc of an erosive convergent margin, Pacific coast, Costa Rica. Tectonics, 23(2):TC2007. doi:10.1029/ 2002TC001464

Flüh, E.R., Söding, E., and Suess, E., 2004. RV Sonne Cruise Report SO173/1, 3, and 4-Subduction II: the Central American continental margin. GEOMAR Rep., 115.

Gans, P.B., Macmillan, I., Alvarado-Inundi, G., Perez, W., and Sigaran, C., 2002. Neogene evolution of the Costa Rican arc. Geol. Soc. Am. Abstr. Progr., 114:224-12. http:/ /gsa.confex.com/gsa/2002AM/finalprogram/ abstract_43501.htm

Goss, A.R., and Kay, S.M., 2006. Steep REE patterns and enriched $\mathrm{Pb}$ isotopes in southern Central American arc magmas: evidence for forearc subduction erosion? Geochem., Geophys., Geosyst., 7(5):Q05016. doi:10.1029/ 2005 GC001163

Gräfe, K., Frisch, W., Villa, I.M., and Meschede, M., 2002. Geodynamic evolution of southern Costa Rica related to low-angle subduction of the Cocos Ridge: constraints from thermochronology. Tectonophysics, 348(4):187204. doi:10.1016/S0040-1951(02)00113-0

Grevemeyer, I., Kopf, A.J., Fekete, N., Kaul, N., Villinger, H.W., Heesemann, M., Wallmann, K., Spiess, V., Gennerich, H.-H., Muller, M., and Weinrebe, W., 2004. Fluid flow through active mud dome Mound Culebra offshore Nicoya Peninsula, Costa Rica: evidence from heat flow surveying. Mar. Geol., 207(1-4):145-157. doi:10.1016/j.margeo.2004.04.002

Harris, R.N., Grevemeyer, I., Ranero, C.R., Villinger, H., Barckhausen, U., Henke, T., Mueller, C., and Neben, S., 2010a. Thermal regime of the Costa Rican convergent margin: 1. Along-strike variations in heat flow from probe measurements and estimated from bottom-simulating reflectors. Geochem., Geophys., Geosyst., 11(12):Q12S28. doi:10.1029/2010GC003272

Harris, R.N., Spinelli, G., Ranero, C.R., Grevemeyer, I., Villinger, H., and Barckhausen, U., 2010b. Thermal regime of the Costa Rican convergent margin: 2. Thermal models of the shallow Middle America subduction zone offshore Costa Rica. Geochem., Geophys., Geosyst., 11(12):Q12S29. doi:10.1029/2010GC003273
Harris, R.N., and Wang, K., 2002. Thermal models of the Middle America Trench at the Nicoya Peninsula, Costa Rica. Geophys. Res. Lett., 29(21):2010-2013. doi:10.1029/2002GL015406

Hauff, F., Hoernle, K., Schminke, H.-U., and Werner, R., 1997. A mid-Cretaceous origin for the Galápagos hotspot: volcanological, petrological and geochemical evidence from Costa Rican oceanic crustal segments. Geol. Rundsch., 86(1):141-155. doi:10.1007/ PL00009938

Hauff, F., Hoernle, K., Tilton, G., Graham, D.W., and Kerr, A.C., 2000. Large volume recycling of oceanic lithosphere over short time scales: geochemical constraints from the Caribbean Large Igneous Province. Earth Planet. Sci. Lett., 174(3-4):247-263. doi:10.1016/S0012821X(99)00272-1

Heesemann, M., Villinger, H., Jannasch, H.W., Kastner, M., and the Expedition 301T Scientists, 2006. Data report: long-term temperature measurements in Holes 1253A and 1255A off Costa Rica, ODP Leg 205. In Morris, J.M., Villinger, H.W., and Klaus, A. (Eds.), Proc. ODP, Sci. Results, 205: College Station, TX (Ocean Drilling Program), 1-20. doi:10.2973/odp.proc.sr.205.209.2006

Hensen, C., Wallmann, K., Schmidt, M., Ranero, C.R., and Suess, E., 2004. Fluid expulsion related to mud extrusion off Costa Rica-a window to the subducting slab. Geology, 32(3):201-204. doi:10.1130/G20119.1

Herrstrom, E.A., Reagan, M.K., and Morris, J.D., 1995. Variations in lava composition associated with flow of asthenosphere beneath southern Central America. Geology, 23(7):617-620. doi:10.1130/0091-

7613(1995)023<0617:VILCAW>2.3.CO;2

Hey, R., 1977. Tectonic evolution of the Cocos-Nazca spreading center. Geol. Soc. Am. Bull., 88(12):1404-1420. doi:10.1130/0016-7606(1977)88<i:TEOTCS>2.0.CO;2

Hinz, K., von Huene, R., Ranero, C.R., and the PACOMAR Working Group, 1996. Tectonic structure of the convergent Pacific margin offshore Costa Rica from multichannel seismic reflection data. Tectonics, 15(1):54-66. doi:10.1029/95TC02355

Hoernle, K., Abt, D.L., Fischer, K.M., Nichols, H., Hauff, F., Abers, G.A., van den Bogaard, P., Heydolph, K.,

Alvarado, G., Protti, M., and Strauch, W., 2008. Arc-parallel flow in the mantle wedge beneath Costa Rica and Nicaragua. Nature (London, U. K.), 451(7182):1094-1097. doi:10.1038/nature06550

Hoernle, K., van den Bogaard, P., Werner, R., Lissinna, B., Hauff, F., Alvarado, G., and Garbe-Schönberg, D., 2002. Missing history (16-71 Ma) of the Galápagos hotspot: implications for the tectonic and biological evolution of the Americas. Geology, 30(9):795-798. doi:10.1130/ 0091-7613(2002)030<0795:MHMOTG>2.0.CO;2

Hoernle, K., Werner, R., Phipps Morgan, J., Garbe-Schönberg, D., Bryce, J., and Mrazek, J., 2000. Existence of a complex spatial zonation in the Galápagos plume. Geology, 28(5):435-438. doi:10.1130/00917613(2000)28<435:EOCSZI>2.0.CO;2

Hutnak, M., Fisher, A.T., Harris, R., Stein, C., Wang, K., Spinelli, G., Schindler, M., Villinger, H., and Silver, E., 
2008. Large heat and fluid fluxes driven through midplate outcrops on ocean crust. Nat. Geosci., 1(9):611614. doi:10.1038/ngeo264

Hutnak, M., Fisher, A.T., Stein, C.A., Harris, R., Wang, K., Silver, E., Spinelli, G., Pfender, M., Villinger, H., MacKnight, R., Costa, P.P., DeShon, H.R., and Diamente, C., 2007. The thermal state of 18-24 Ma upper lithosphere subducting below the Nicoya Peninsula, northern Costa Rica margin. In Dixon, T.H., and Moore, J.C. (Eds.), The Seismogenic Zone of Subduction Thrust Faults: New York (Columbia Univ. Press), 86-122.

Hutnak, M., Fisher, A.T., Zühlsdorff, L., Spiess, V., Stauffer, P.H., and Gable, C.W., 2006. Hydrothermal recharge and discharge guided by basement outcrops on 0.7-3.6 Ma seafloor east of the Juan de Fuca Ridge: observations and numerical models. Geochem., Geophys., Geosyst., 7(7):Q07O02. doi:10.1029/2006GC001242

Jannasch, H.W., Davis, E.E., Kastner, M., Morris, J.D., Pettigrew, T.L., Plant, J.N., Solomon, E.A., Villinger, H.W., and Wheat, C.G., 2003. CORK-II: long-term monitoring of fluid chemistry, fluxes, and hydrology in instrumented boreholes at the Costa Rica subduction zone. In Morris, J.D., Villinger, H.W., Klaus, A., Proc. ODP, Init. Repts., 205: College Station, TX (Ocean Drilling Program), 1-36. doi:10.2973/odp.proc.ir.205.102.2003

Jordan, B.R., Sigurdsson, H., Carey, S.N., Rogers, R., and Ehrenborg, J., 2006. Geochemical correlation of Caribbean Sea tephra layers with ignimbrites in Central America. In Siebe, C., Macias Gerardo, J.L., and AguirreDíaz, G.J. (Eds.), Neogene-Quaternary Continental Margin Volcanism: A Perspective from México. Spec. Pap.-Geol. Soc. Am., 402:175-208. doi:10.1130/2006.2402(08)

Kahn, L.M., Silver, E.A., Orange, D., Kochevar, R., and McAdoo, B., 1996. Surficial evidence of fluid expulsion from the Costa Rica accretionary prism. Geophys. Res. Lett., 23(8):887-890. doi:10.1029/96GL00732

Kastner, M., Solomon, E., Wei, W., Chan, L.-H., and Saether, O.M., 2006. Data report: chemical and isotopic compositions of pore fluids and sediments from across the Middle America Trench, offshore Costa Rica. In Morris, J.D., Villinger, H.W., and Klaus, A. (Eds.), Proc. ODP, Sci Results, 205: College Station, TX (Ocean Drilling Program), 1-21. doi:10.2973/ odp.proc.sr.205.208.2006

Kimura, G., Silver, E.A., Blum, P., et al., 1997. Proc. ODP, Init. Repts., 170: College Station, TX (Ocean Drilling Program). doi:10.2973/odp.proc.ir.170.1997

Kinoshita, M., Tobin, H., Ashi, J., Kimura, G., Lallemant, S., Screaton, E.J., Curewitz, D., Masago, H., Moe, K.T., and the Expedition 314/315/316 Scientists, 2009. Proc. IODP, 314/315/316: Washington, DC (Integrated Ocean Drilling Program Management International, Inc.). doi:10.2204/iodp.proc.314315316.2009

Klaucke, I., Masson, D.G., Petersen, C.J., Weinrebe, W., and Ranero, C.R., 2008. Multifrequency geoacoustic imaging of fluid escape structures offshore Costa Rica: implications for the quantification of seep processes. Geochem., Geophys., Geosys., 9(4):Q04010. doi:10.1029/ 2007GC001708
Kolarsky, R.A., Mann, P., and Montero, W., 1995. Island arc response to shallow subduction of the Cocos Ridge, Costa Rica. In Mann, P. (Ed.), Geologic and Tectonic Development of the Caribbean Plate Boundary in Southern Central America. Spec. Pap.-Geol. Soc. Am., 295:235-262.

Kutterolf, S., Freundt, A., Peréz, W., Mörz, T., Schacht, U., Wehrmann, H., and Schmincke, H.-U., 2008. Pacific offshore record of plinian arc volcanism in Central America: 1. Along-arc correlations. Geochem., Geophys., Geosyst., 9(2):Q02S01. doi:10.1029/2007GC001631

LaFemina, P., Dixon, T.H., Govers, R., Norabuena, E., Turner, H., Saballos, A., Mattioli, G., Protti, M., and Strauch, W., 2009. Fore-arc motion and Cocos Ridge collision in Central America. Geochem., Geophys., Geosyst., 10(5):Q05S14. doi:10.1029/2008GC002181

Langseth, M.G., and Silver, E.A., 1996. The Nicoya convergent margin-a region of exceptionally low heat flow. Geophys. Res. Lett., 27(8):891-894. doi:10.1029/ 96GL00733

Lonsdale, P., and Klitgord, K.D., 1978. Structure and tectonic history of the eastern Panama Basin. Geol. Soc. Am. Bull., 89(7):981-999. doi:10.1130/ 0016-7606(1978)89<981:SATHOT>2.0.CO;2

MacMillan, I., Gans, P.B., and Alvarado, G., 2004. Middle Miocene to present plate tectonic history of the southern Central American Volcanic Arc. Tectonophysics, 392(1-4)325-348. doi:10.1016/j.tecto.2004.04.014

McAdoo, B.G., Orange, D.L., Silver, E.A., McIntosh, K., Abott, L., Galewsky, J., Kahn, L., and Protti, M., 1996. Seafloor structural observations, Costa Rica accretionary prism. Geophys. Res. Lett., 23(8):883-886. doi:10.1029/ 96GL00731

McIntosh, K., Silver, E., and Shipley, T., 1993. Evidence and mechanisms for forearc extension at the accretionary Costa Rica convergent margin. Tectonics, 12(6):13801392. doi:10.1029/93TC01792

Meschede, M., Zweigel, P., and Kiefer, E., 1999. Subsidence and extension at a convergent plate margin: evidence for subduction erosion off Costa Rica. Terra Nova, 11(23):112-117. doi:10.1046/j.1365-3121.1999.00234.x

Mikada, H., Becker, K., Moore, J.C., Klaus, A., et al., 2002. Proc. ODP, Init. Repts., 196: College Station, TX (Ocean Drilling Program). doi:10.2973/odp.proc.ir.196.2002

Moore, J.C., Klaus, A., et al., 1998. Proc. ODP, Init. Repts., 171A: College Station, TX (Ocean Drilling Program). doi:10.2973/odp.proc.ir.171A.1998

Mora, C., 1979. Estudio geológico de una parte de la región sureste del Valle del General, Provincia de Puntarenas, Costa Rica [Tesis de Licenciatura]. Univ. Costa Rica, San José.

Morris, J., Valentine, R., and Harrison, T., 2002. ${ }^{10}$ Be imaging of sediment accretion and subduction along the northeast Japan and Costa Rica convergent margins. Geology, 30(1):59-62. doi:10.1130/00917613(2002)030<0059:BIOSAA>2.0.CO;2

Morris, J.D., Villinger, H.W., Klaus, A., et al., 2003. Proc. ODP, Init. Repts., 205: College Station, TX (Ocean Drilling Program). doi:10.2973/odp.proc.ir.205.2003 
Newman, A.V., Schwartz, S.Y., Gonzalez, V., DeShon, H.R., Protti, J.M., and Dorman, L.M., 2002. Along-strike variability in the seismogenic zone below Nicoya Peninsula, Costa Rica. Geophys. Res. Lett., 29(20):1977. doi:10.1029/2002GL015409

Norabuena, E., Dixon, T.H., Schwartz, S., DeShon, H., Newman, A., Protti, M., Gonzalez, V., Dorman, L., Flueh, E.R., Lundgren, P., Pollitz, F., and Sampson, D., 2004. Geodetic and seismic constraints on some seismogenic zone processes in Costa Rica. J. Geophys. Res., [Solid Earth], 109(B11):B11403. doi:10.1029/2003JB002931

Park, J.-O., Tsuru, T., Kodaira, S., Cummins, P.R., and Kaneda, Y., 2002. Splay fault branching along the Nankai subduction zone. Science, 297(5584):1157-1160. doi:10.1126/science.1074111

Patino, L.C., Carr, M.J., and Feigenson, M.D., 1997. Crossarc geochemical variations in volcanic fields in Honduras C.A.: progressive changes in source with distance from the volcanic front. Contrib. Mineral. Petrol., 129(4):341-351. doi:10.1007/s004100050341

Patino, L.C., Carr, M.J., and Feigenson, M.D., 2000. Local and regional variations in Central American arc lavas controlled by variations in subducted sediment input. Contrib. Mineral. Petrol., 138:265-283. doi:10.1007/ s004100050562

Pérez, W., Alvarado, G.E., and Gans, P.B., 2006. The 322 ka Tiribí Tuff: stratigraphy, geochronology, and mechanisms of deposition of the largest and most recent ignimbrite in the Valle Central, Costa Rica. Bull. Volcanol., 69(1):25-40. doi:10.1007/s00445-006-0053-X

Petersen, C.J., Klaucke, I., Weinrebe, W., and Ranero, C.R., 2009. Fluid seepage and mound formation offshore Costa Rica revealed by deep-towed sidescan sonar and sub-bottom profiler data. Mar. Geol., 266(1-4):172-181. doi:10.1016/j.margeo.2009.08.004

Protti, M., Gonzalez, V., Kato, T., Iinuma, T., Miyazaki, S., Obana, K., Kaneda, Y., La Femina, P., Dixon, T., and Schwartz, S., 2004. A creep event on the shallow interface of the Nicoya Peninsula, Costa Rica seismogenic zone. Eos, Trans. Am. Geophys. Union,

85(47)(Suppl.):F1378. (Abstract) http://www.agu.org/ meetings/fm04/waisfm04.html

Ranero, C.R., Grevemeyer, I., Sahling, U., Barckhausen, U., Hensen, C., Wallmann, K., Weinrebe, W., Vannucchi, P., von Huene, R., and McIntosh, K., 2008. Hydrogeological system of erosional convergent margins and its influence on tectonics and interplate seismogenesis. Geochem., Geophys., Geosyst., 9(3):Q03S04. doi:10.1029/ 2007GC001679

Ranero, C.R., and von Huene, R., 2000. Subduction erosion along the Middle America convergent margin. Nature (London, U. K.), 404(6779):748-752. doi:10.1038/ 35008046

Ranero, C.R., von Huene, R., Flueh, E., Duarte, M., Baca, D., and McIntosh, K., 2000. A cross section of the convergent Pacific margin of Nicaragua. Tectonics, 19(2):335-357. doi:10.1029/1999TC900045

Reagan, M.K., and Gill, J.B., 1989. Coexisting calcalkaline and high-niobium basalts from Turrialba Volcano,
Costa Rica: implications for residual titanates in arc magma sources. J. Geophys. Res., [Solid Earth], 94(B4):4619-4633. doi:10.1029/JB094iB04p04619

Rose, W.I., Conway, F.M., Pullinger, C.R., Deino, A., and McIntosh, W.C., 1999. An improved age framework for late Quaternary silicic eruptions in northern Central America. Bull. Volcanol., 61(1-2):106-120. doi:10.1007/ s004450050266

Ruppel, C., and Kinoshita, M., 2000. Fluid, methane, and energy flux in an active margin gas hydrate province, offshore Costa Rica. Earth Planet. Sci. Lett., 179(1):153165. doi:10.1016/S0012-821X(00)00096-0

Saffer, D., McNeill, L., Byrne, T., Araki, E., Toczko, S., Eguchi, N., Takahashi, K., and the Expedition 319 Scientists, 2010. Proc. IODP, 319: Tokyo (Integrated Ocean Drilling Program management International, Inc.). doi:10.2204/iodp.proc.319.2010

Sak, P.B., Fisher, D.M., and Gardner, T.W., 2004. Effects of subducting seafloor roughness on upper plate vertical tectonism: Osa Peninsula, Costa Rica. Tectonics, 23(1):TC1017-TC1032. doi:10.1029/2002TC001474

Shipley, T.H., McIntosh, K.D., Silver, E.A., and Stoffa, P.L., 1992. Three-dimensional seismic imaging of the Costa Rica accretionary prism: structural diversity in a small volume of the lower slope. J. Geophys. Res., [Solid Earth], 97(B4):4439-4459. doi:10.1029/91JB02999

Shipley, T.H., Ogawa, Y., Blum, P., et al., 1995. Proc. ODP, Init. Repts., 156: College Station, TX (Ocean Drilling Program). doi:10.2973/odp.proc.ir.156.1995

Sigurdsson, H., Kelley, S., Leckie, R.M., Carey, S., Bralower, T., and King, J., 2000. History of circum-Caribbean explosive volcanism: ${ }^{40} \mathrm{Ar} /{ }^{39} \mathrm{Ar}$ dating of tephra layers. In Leckie, R.M., Sigurdsson, H., Acton, G.D., and Draper, G. (Eds.), Proc. ODP, Sci. Results, 165: College Station, TX (Ocean Drilling Program), 299-314. doi:10.2973/ odp.proc.sr.165.021.2000

Silver, E., Kastner, M., Fisher, A., Morris, J., McIntosh, K., and Saffer, D., 2000. Fluid flow paths in the Middle America Trench and Costa Rica margin. Geology, 28(8):679-682. doi:10.1130/00917613(2000)28<679:FFPITM>2.0.CO;2

Sinton, C.W., Duncan, R.A., and Denyer, P., 1997. Nicoya Peninsula, Costa Rica: a single suite of Caribbean oceanic plateau magmas. J. Geophys. Res., [Solid Earth], 102(B7):15507-15520. doi:10.1029/97JB00681

Sinton, C.W., Duncan, R.A., Storey, M., Lewis, J., and Estrada, J.J., 1998. An oceanic flood basalt province within the Caribbean plate. Earth Planet. Sci. Lett., 155(3-4):221-235. doi:10.1016/ S0012-821X(97)00214-8

Sitchler, J.C., Fisher, D.M., Gardner, T.W., and Protti, M., 2007. Constraints on inner forearc deformation from balanced cross sections, Fila Costeña thrust belt, Costa Rica. Tectonics, 26(6):TC6012. doi:10.1029/ 2006TC001949

Smith, W.H.F., and Sandwell, D.T., 1997. Global sea floor topography from satellite altimetry and ship depth soundings. Science, 277(5334):1956-1962. doi:10.1126/ science.277.5334.1956 
Solomon, E.A., Kastner, M., Wheat, C.G., Jannasch, H., Robertson, G., Davis, E.E., and Morris, J.D., 2009. Longterm hydrogeochemical records in the oceanic basement and forearc prism at the Costa Rica subduction zone. Earth Planet. Sci. Lett., 282(1-4):240-251. doi:10.1016/j.epsl.2009.03.022

Spinelli, G.A., and Saffer, D.M., 2004. Along-strike variations in underthrust sediment dewatering on the Nicoya margin, Costa Rica related to the updip limit of seismicity. Geophys. Res. Lett., 31(4):L04613. doi:10.1029/2003GL018863

Sprechmann, P. (Ed.), 1984. Manual de Geología de Costa Rica: Estratigrafía (Vol. 1): San José (Univer. Costa Rica).

Stavenhagen, A.U., Flueh, E.R., Ranero, C., McIntosh, K.D., Shipley, T., Leandro, G., Shulze, A., and Danobeitia, J.J., 1998. Seismic wide-angle investigations in Costa Rica: a crustal velocity model from the Pacific to the Caribbean coast. Zb. Geol. Paläontol., 1997(3-6):393-408.

Stein, C.A., and Stein, S., 1994. Constraints on hydrothermal heat flux through the oceanic lithosphere from global heat flow. J. Geophys. Res., [Solid Earth], 99(B2):3081-3095. doi:10.1029/93JB02222

Sutter, F.R., 1985. Sección geológica del Pacífico al Atlántico a través de Costa Rica. Rev. Geol. Am. Cent., 2:23-32. http://www.geologia.ucr.ac.cr/revista/to_pdf/ revista/02/02-RIVIER.pdf

Vacquier, V., Sclater, J.G., and Correy, C.E., 1967. Studies of the thermal state of the Earth: heat flow, Eastern Pacific. Bull. Earthquake Res. Inst., 45:375-393.

van Andel, T.H., Heath, G.R., Malfait, B.T., Heinrichs, D.F., and Ewing, J.I., 1971. Tectonics of the Panama Basin, eastern equatorial Pacific. Geol. Soc. Am. Bull., 82(6):1489-1508. doi:10.1130/ 0016-7606(1971)82[1489:TOTPBE]2.0.CO;2

Vannucchi, P., Fisher, D.M., Bier, S., and Gardner, T.W., 2006. From seamount accretion to tectonic erosion: formation of Osa Mélange and the effects of Cocos Ridge subduction in southern Costa Rica. Tectonics, 25(4):TC2004. doi:10.1029/2005TC001855

Vannucchi, P., Galeotti, S., Clift, P.D., Ranero, C.R., and von Huene, R., 2004. Long-term subduction-erosion along the Guatemalan margin of the Middle America Trench. Geology, 32(7):617-620. doi:10.1130/G20422.1

Vannucchi, P., Ranero, C.R., Galeotti, S., Straub, S.M., Scholl, D.W., and McDougall-Ried, K., 2003. Fast rates of subduction erosion along the Costa Rica Pacific margin: implications for nonsteady rates of crustal recycling at subduction zones. J. Geophys. Res., [Solid Earth], 108(B11):2511. doi:10.1029/2002JB002207

Vannucchi, P., Scholl, D.W., Meschede, M., and McDougall-Reid, K., 2001. Tectonic erosion and consequent collapse of the Pacific margin of Costa Rica: combined implications from ODP Leg 170, seismic offshore data, and regional geology of the Nicoya Peninsula. Tectonics, 20(5):649-668. doi:10.1029/2000TC001223

Vogel, T.A., Patino, L.C., Alvarado, G.E., and Gans, P.B., 2004. Silicic ignimbrites within the Costa Rican vol- canic front: evidence for the formation of continental crust. Earth Planet. Sci. Lett., 226(1-2):149-259. doi:10.1016/j.epsl.2004.07.013

Vogel, T.A., Patino, L.C., Eaton, J.K., Valley, J.W., Rose, W.I., Alvarado, G.E., and Viray, E.L., 2006. Origin of silicic magmas along the Central American volcanic front: genetic relationship to mafic melts. J. Volcanol. Geotherm. Res., 156(3-4):217-228. doi:10.1016/j.jvolgeores.2006.03.002

von Herzen, R.P., and Uyeda, S., 1963. Heat flow through the Eastern Pacific Ocean floor. J. Geophys. Res., 68:4219-4250.

von Huene, R., Aubouin, J., et al., 1985. Init. Repts. DSDP, 84: Washington (U.S. Govt. Printing Office). doi:10.2973/dsdp.proc.84.1985

von Huene, R., Bialas, J., Flueh, E., Cropp, B., Csernok, T., Fabel, E., Hoffmann, J., Emeis, K., Holler, P., Jeschke, G., Leandro, M.C., Perez Fernandez, I., Chavarria, S.J., Florez, H.A., Escobedo, Z.D., Leon, R., and Barrios, L.O., 1995. Morphotectonics of the Pacific convergent margin of Costa Rica. In Mann, P. (Ed.), Geologic and Tectonic Development of the Caribbean Plate Boundary in Southern Central America. Spec. Pap.—Geol. Soc. Am., 295:291307.

von Huene, R., and Ranero, C.R., 2003. Subduction erosion and basal friction along the sediment-starved convergent margin off Antofagasta, Chile. J. Geophys. Res., [Solid Earth], 108(B2):2079. doi:10.1029/2001JB001569

von Huene, R., Ranero, C.R., and Vannucchi, P., 2004. Generic model of subduction erosion. Geology, 32(10):913-916. doi:10.1130/G20563.1

von Huene, R., Ranero, C.R., Weinrebe, W., and Hinz, K., 2000. Quaternary convergent margin tectonics of Costa Rica, segmentation of the Cocos plate, and Central American volcanism. Tectonics, 19(2):314-334. doi:10.1029/1999TC001143

Weinrebe, W., and Ranero, C.R. (Eds.), 2003. FS/RV Sonne Cruise Report SO173/2: Seduction, Part A. Seismogenesis and tectonic erosion during subduction: Middle America margin. GEOMAR Rep., 116. http://oceanrep.geomar.de/13407/1/Geomar-Report-116.pdf

Werner, R., Hoernle, K., Barckhausen, U., and Hauff, F., 2003. Geodynamic evolution of the Galápagos hot spot system (central East Pacific) over the past 20 m.y.: constraints from morphology, geochemistry, and magnetic anomalies. Geochem., Geophys., Geosyst., 4(7):1108. doi:10.1029/2003GC000576

Werner, R., Hoernle, K., van den Bogaard, P., Ranero, C., von Huene, R., and Korich, D., 1999. Drowned 14-m.y.old Galápagos archipelago off the coast of Costa Rica: implications for tectonic and evolutionary models. Geology, 27(6):499-502. doi:10.1130/00917613(1999)027<0499:DMYOGP>2.3.CO;2

Ye, S., Bialas, J., Flueh, E.R., Stavenhagen, A., von Huene, R., Leandro, G., and Hinz, K., 1996. Crustal structure of the Middle American Trench off Costa Rica from wide- 
angle seismic data. Tectonics, 15(5):1006-1021. doi:10.1029/96TC00827

Zoback, M.D., Barton, C.A., Brudy, M., Castillo, D.A., Finkbeiner, T., Grollimund, B.R., Moos, D.B., Peska, P., Ward, C.D., and Wiprut, D.J., 2003. Determination of stress orientation and magnitude in deep wells. Int. J. Rock
Mech. Min. Sci., 40(7-8):1049-1076. doi:10.1016/ j.ijrmms.2003.07.001

Publication: 12 April 2012

MS 334-101 
Figure F1. Bathymetric map of Middle America Trench, showing location of proposed drilling area. Note the collision of Cocos Ridge with the trench in the Osa Peninsula area, a process that brings the seismogenic zone within reach of IODP riser drilling capabilities. Elevation data compiled from Smith and Sandwell (1997).

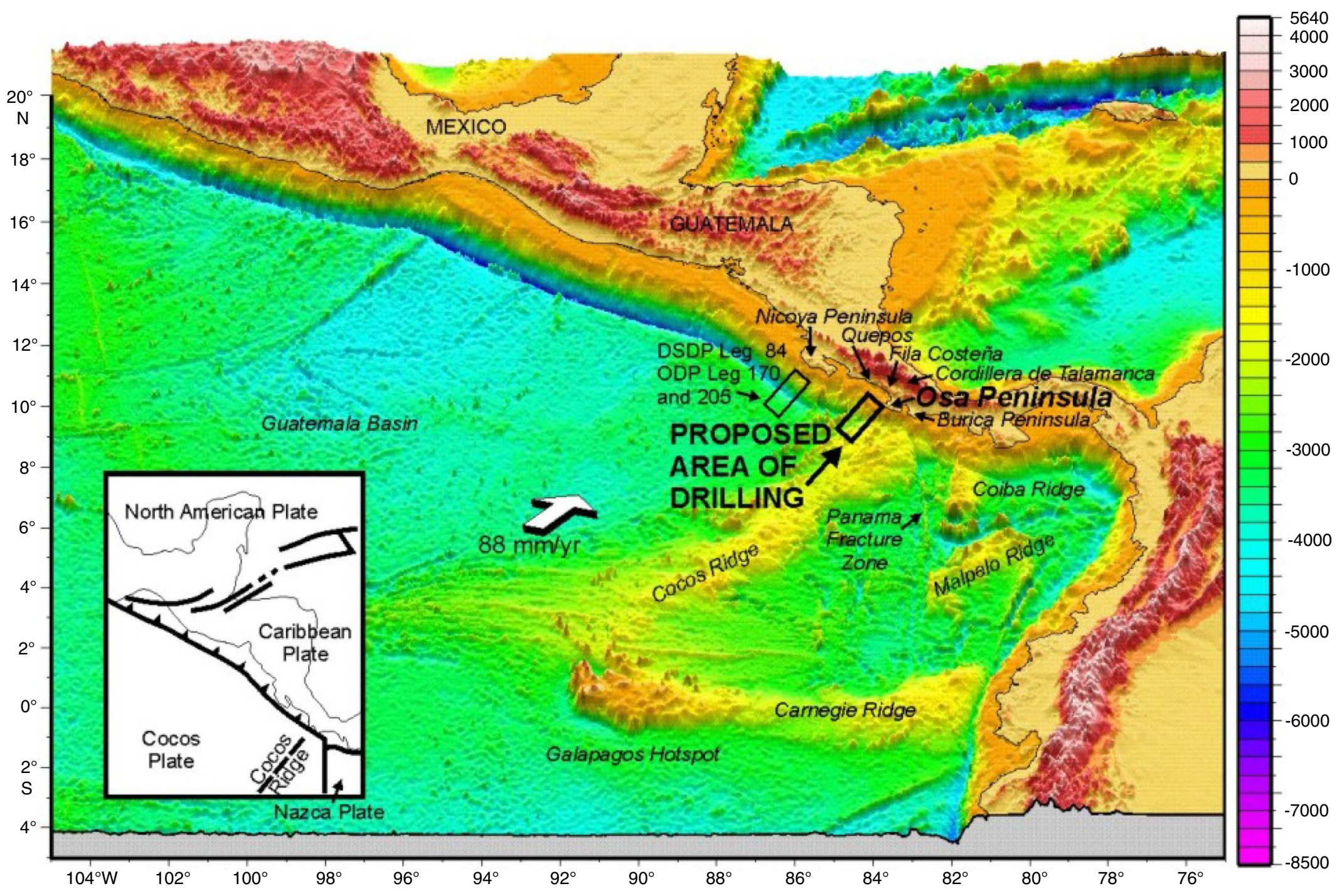


Figure F2. Seismic BGR99 Line 7 showing location of drill sites across Costa Rica margin offshore Osa Peninsula. Prestack depth migration (C.R. Ranero, unpubl. data) is at a vertical exaggeration of $1.3 \times$. CMP $=$ common midpoint.

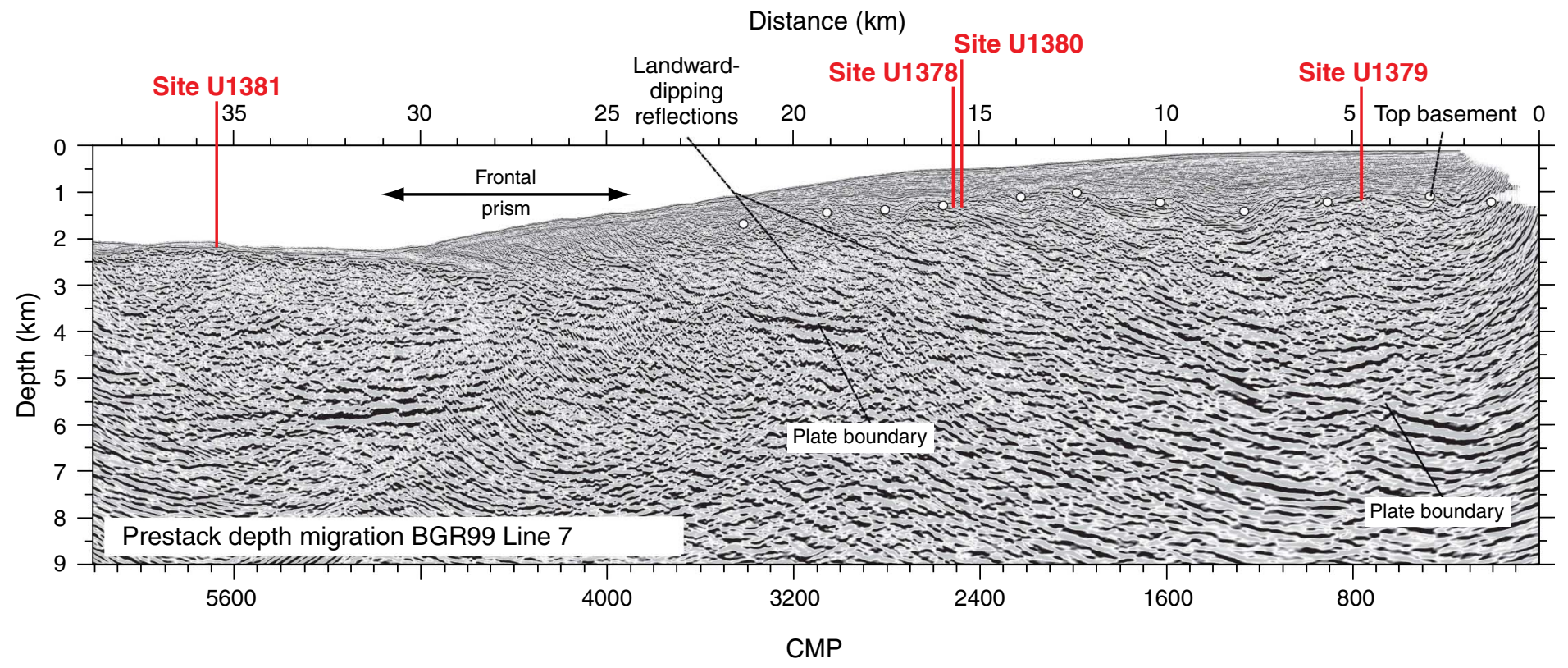


Figure F3. Interpreted wide-angle seismic section (TICOSECT profile 300) from Stavenhagen et al. (1998). Schematic figure through Osa Peninsula margin showing Sites U1378 and U1379 and alternate Sites CRIS-1 and CRIS-2. VE = vertical exaggeration, $\mathrm{v}=P$-wave velocity.

\section{Osa Peninsula}

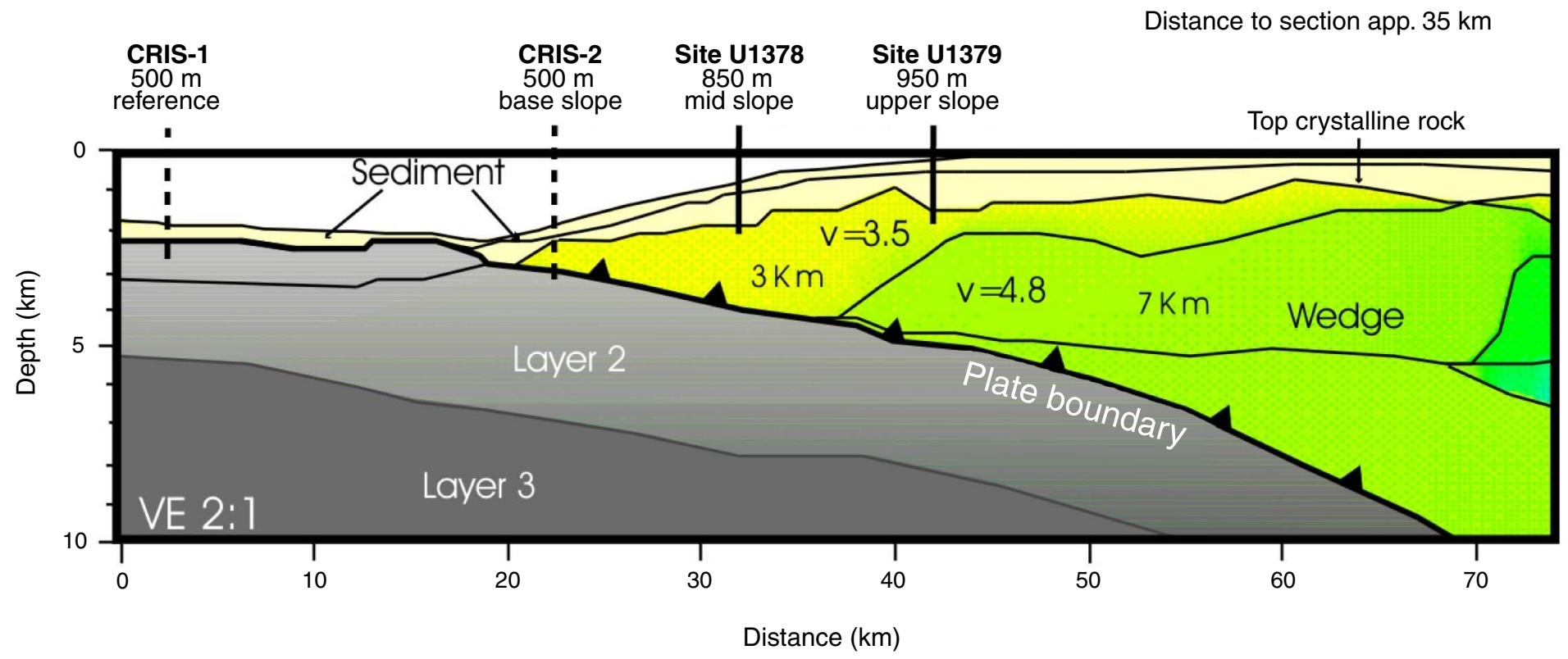




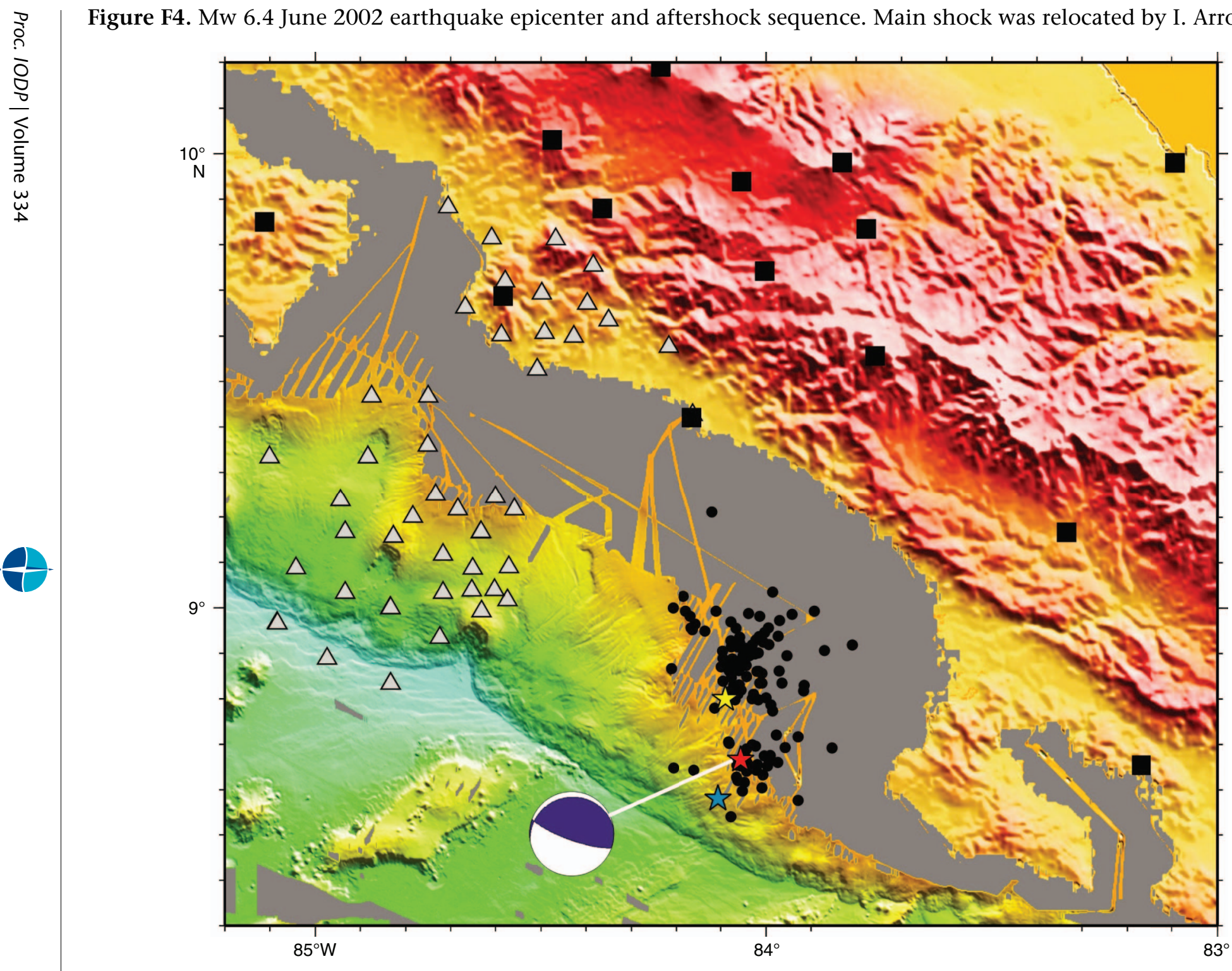

Mw 6.4 June 2002

Main shock, after.

论 This study

S. Husen (pers. comm.)

th s. Bilek (pers. comm.)

- Costa Rica national seismological network

$\triangle \begin{aligned} & \text { German off-shore } \\ & \text { seismological netwo }\end{aligned}$ 
Figure F5. Central America focus site activity map (2008; media.marine-geo.org/image/central-americafocus-site-activity-map-2008-0/). SEIZE = seismogenic zone experiment, OBS = ocean-bottom seismometers, TUCAN = Tomography Under Costa Rica and Nicaragua, CORKS = circulation obviation retrofit kits, MCS = multichannel seismic, CRISP = Costa Rica Seismogenesis Project.

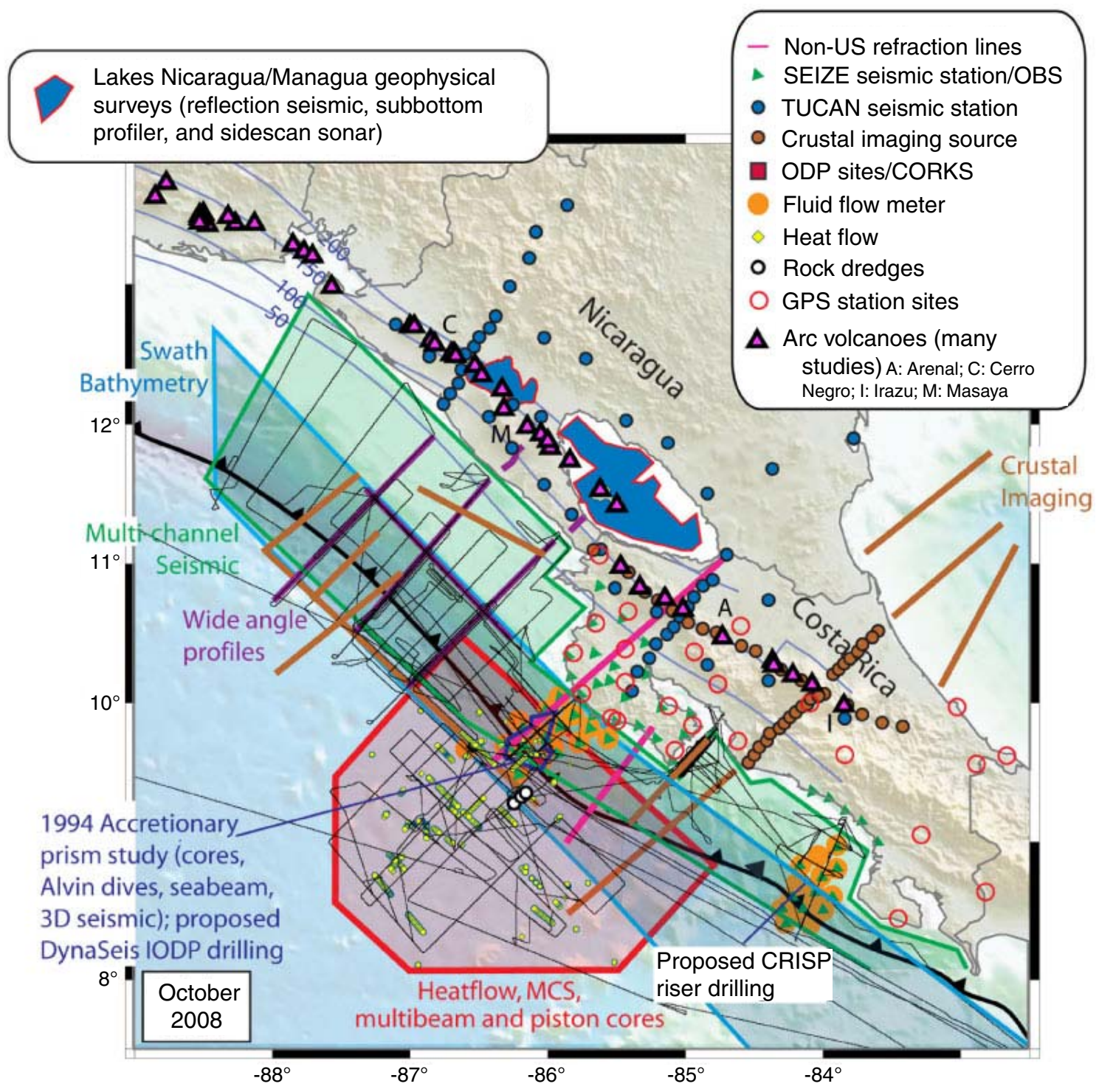


Figure F6. Location of Expedition 334 drill sites. Green squares = primary and contingency sites, yellow squares $=$ alternate and contingency sites, red lines $=$ seismic reflection BGR99 profiles.

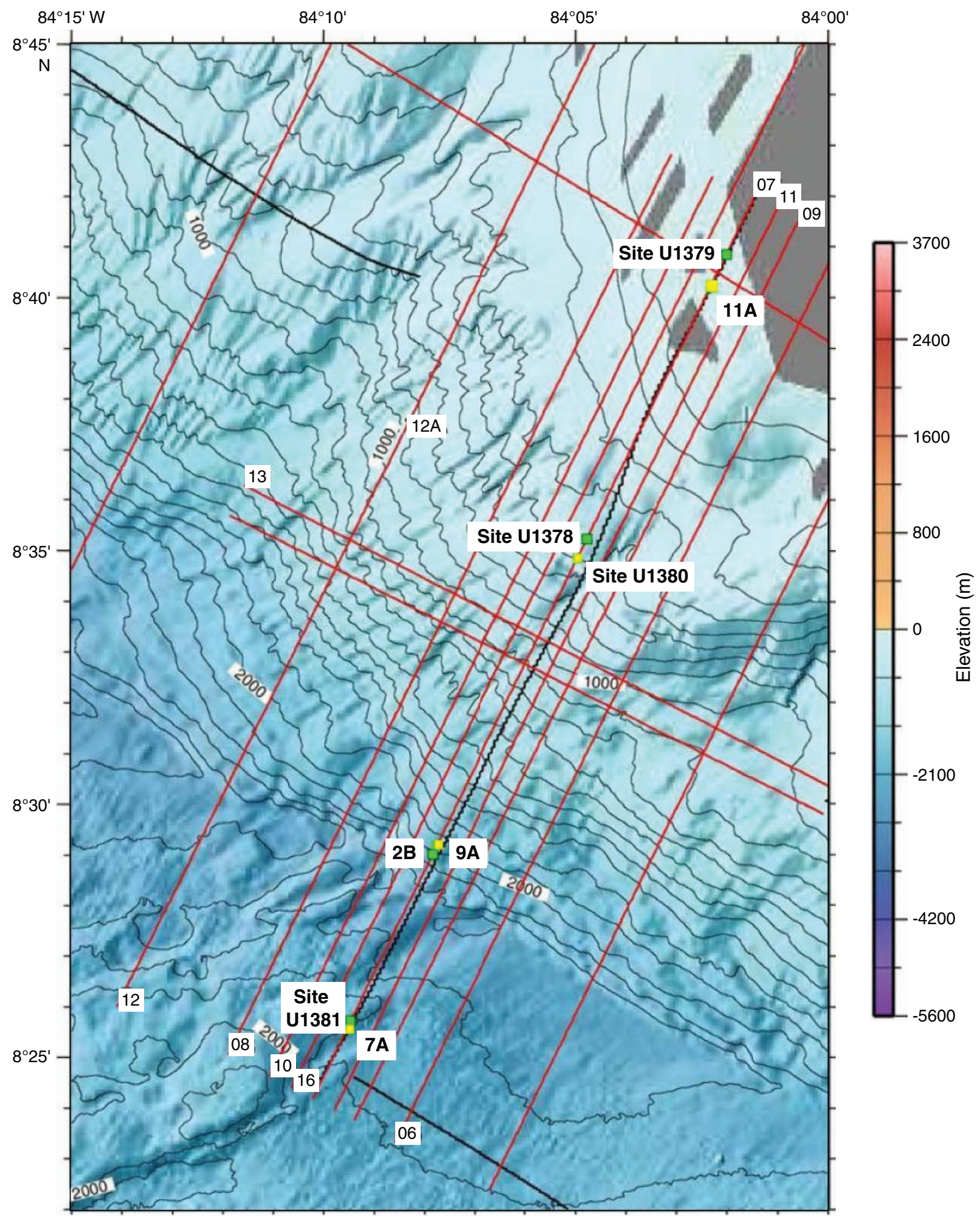


Figure F7. Summary of lithostratigraphic, physical property, and geochemical data obtained onboard, Hole U1378B. A. 0-280 mbsf. (Continued on next page.)

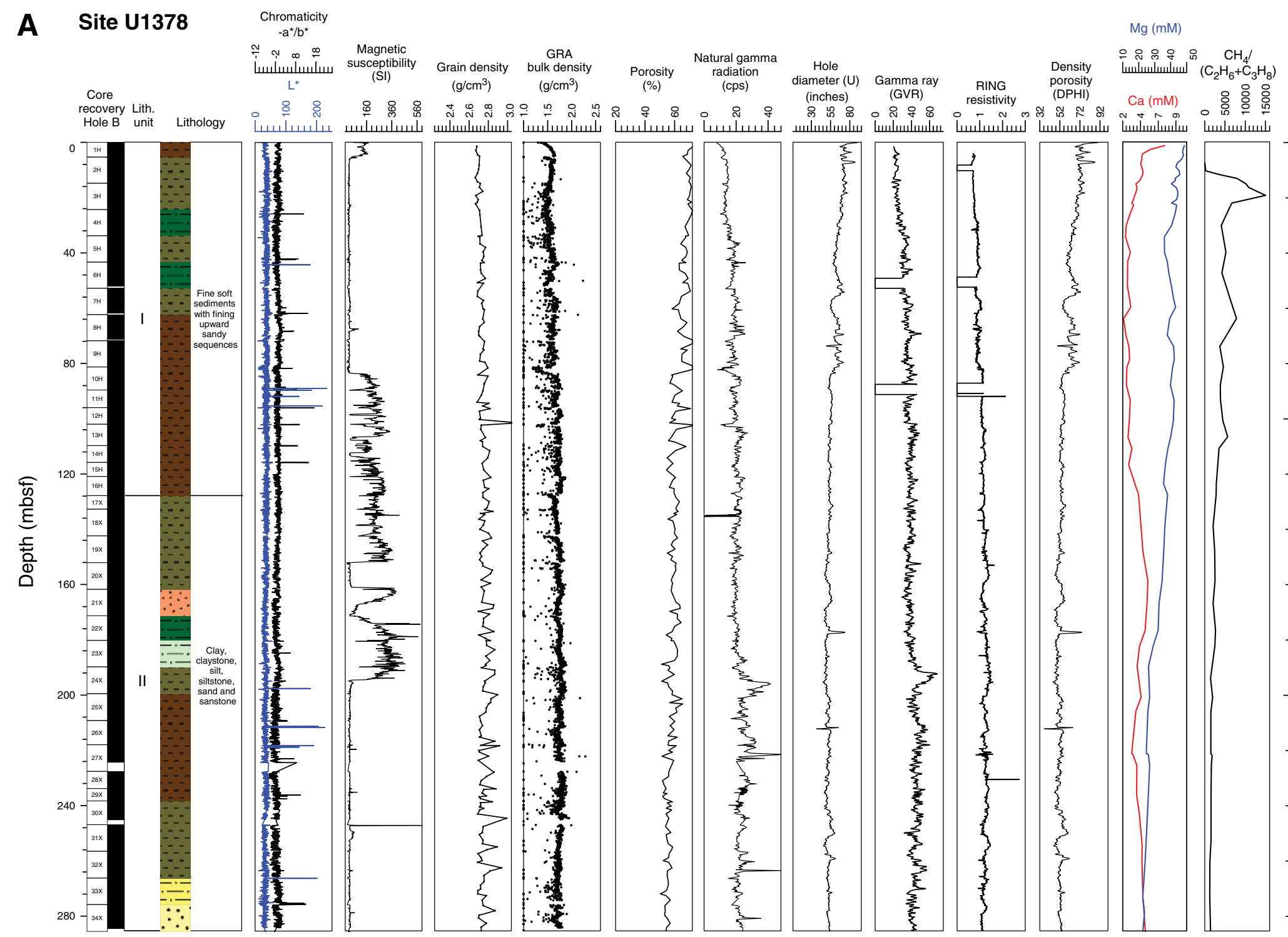




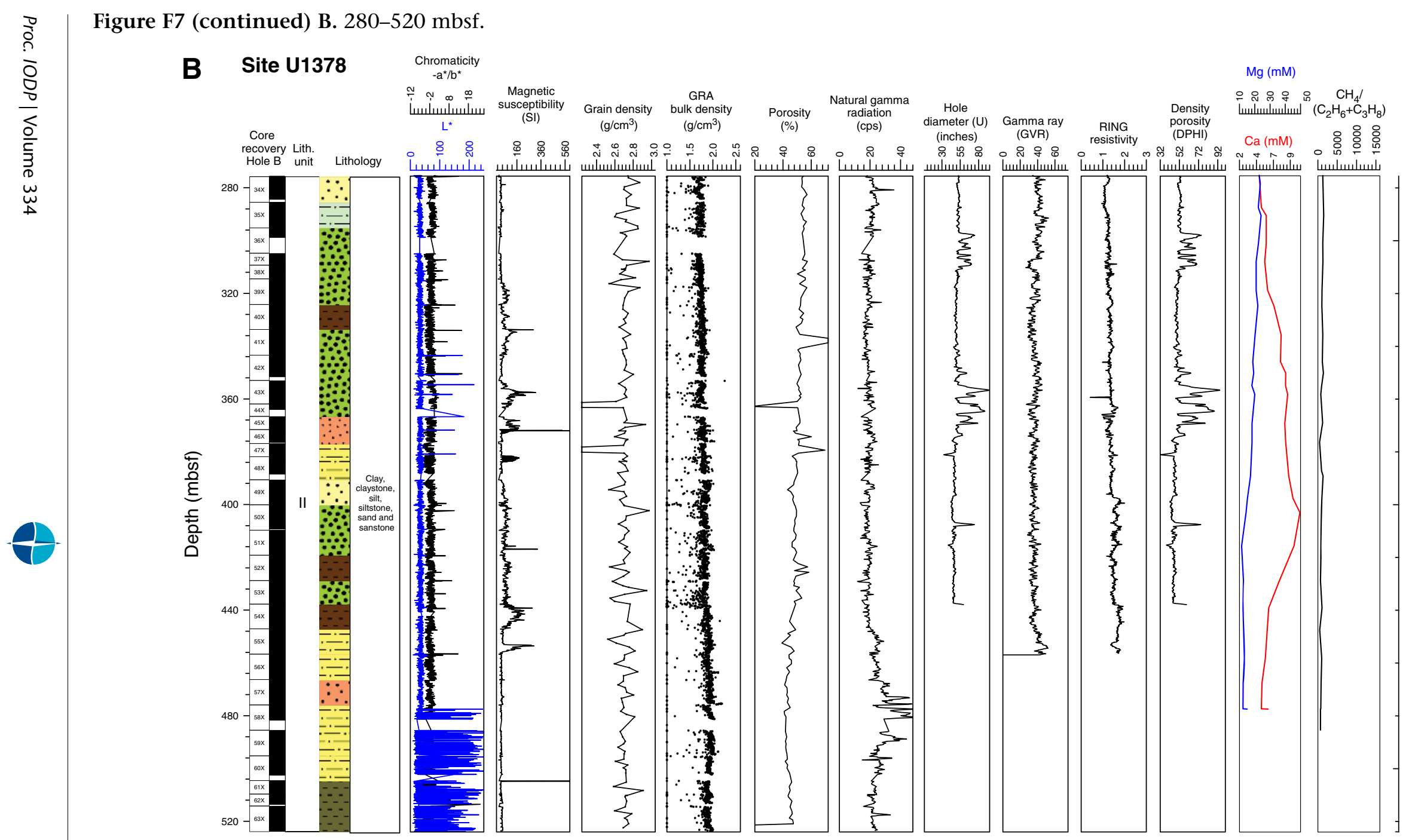


Figure F8. Summary of lithostratigraphic, physical property, and geochemical data obtained onboard, Hole U1379C. A. 0-400 mbsf. (Continued on next page.)

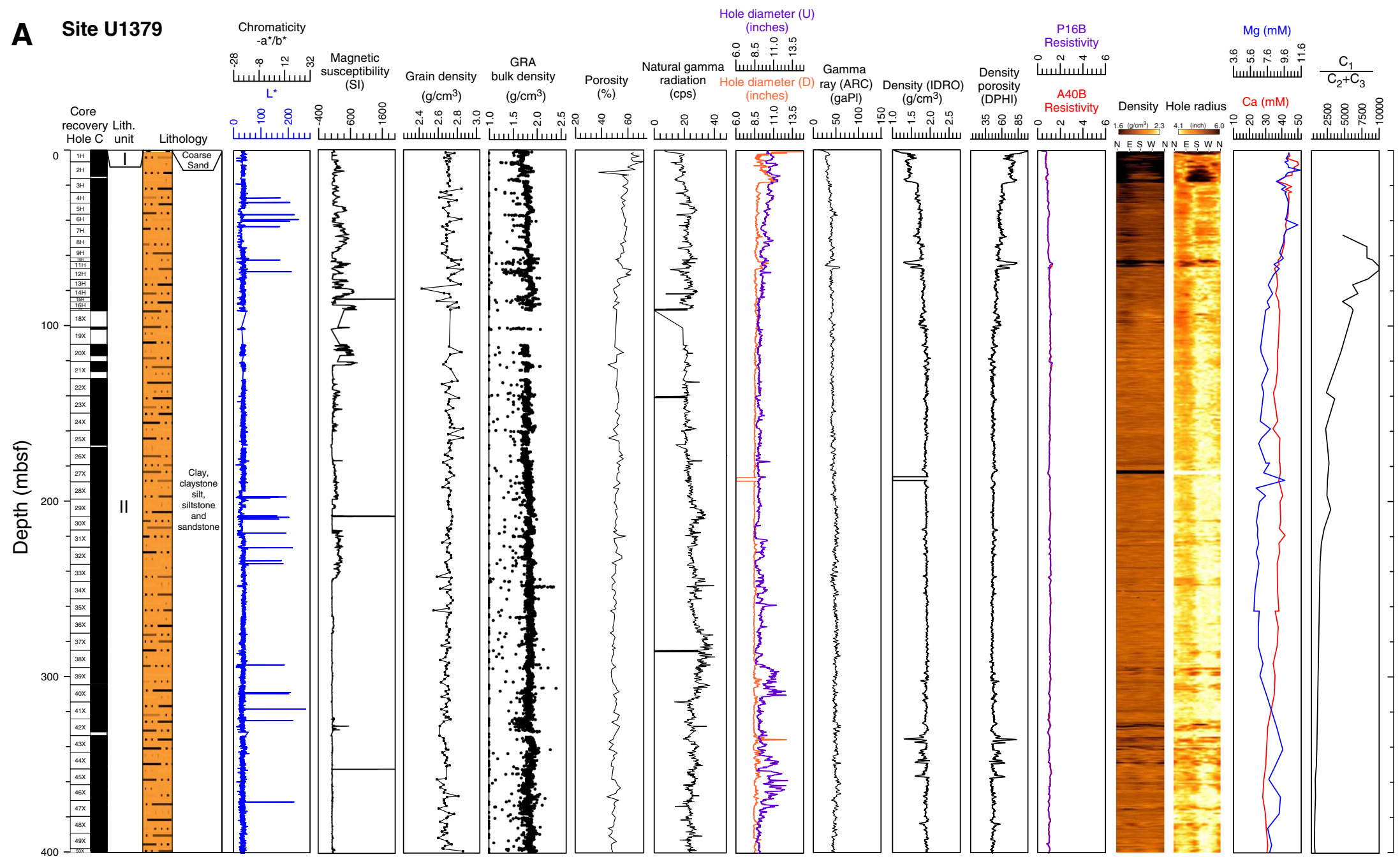




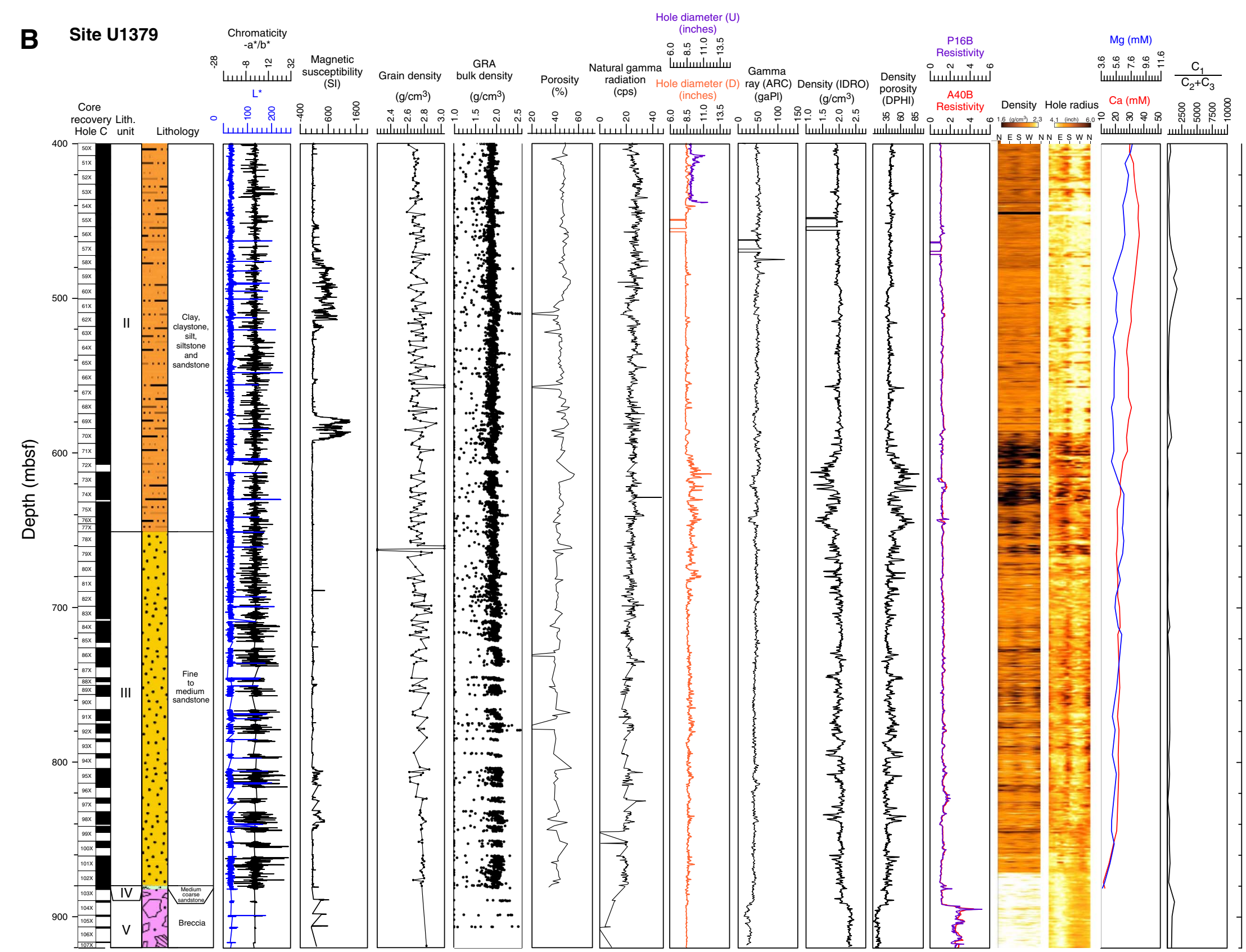


Figure F9. Summary of lithostratigraphic, physical property, and geochemical data obtained onboard, Hole U1380A.

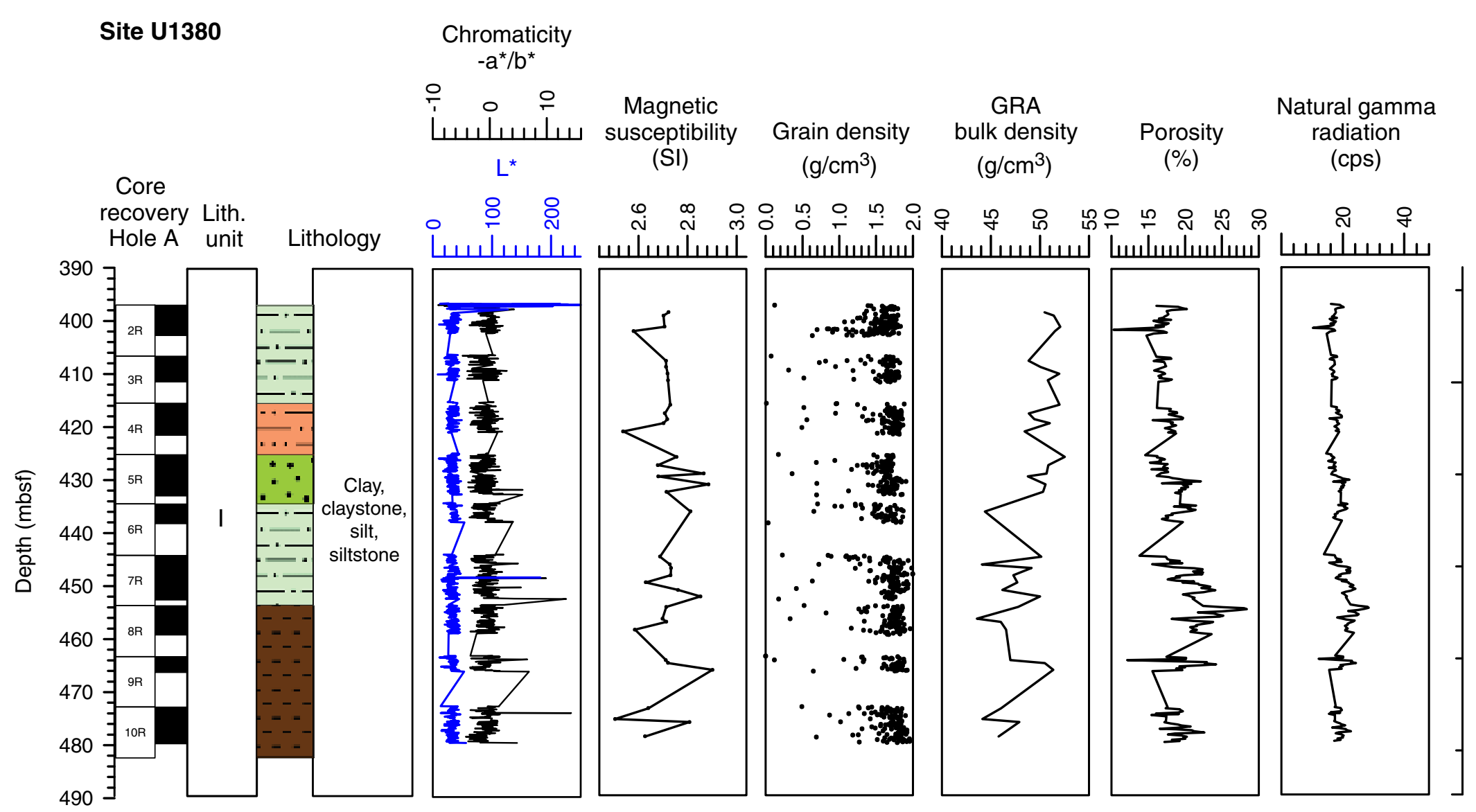


Figure F10. Summary of lithostratigraphic, physical property, and geochemical data obtained onboard, Hole U1381A.

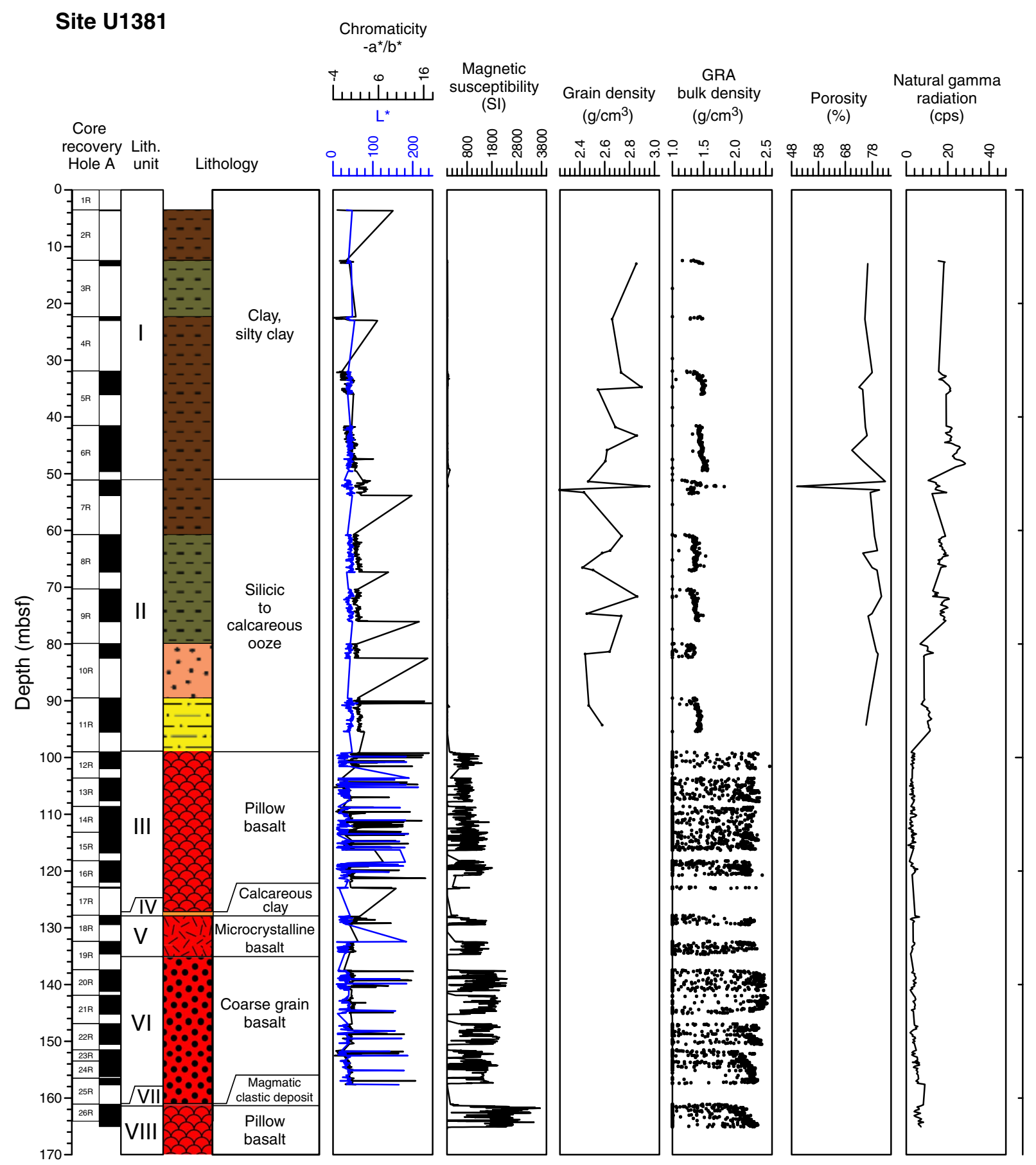


Table T1. Expedition 334 site summary.

\begin{tabular}{|c|c|c|c|c|c|c|c|c|c|c|c|c|c|}
\hline Site & Hole & Latitude & Longitude & $\begin{array}{l}\text { Seafloor } \\
\text { depth } \\
\text { (mbrf) }\end{array}$ & $\begin{array}{l}\text { Cores } \\
(N)\end{array}$ & $\begin{array}{c}\text { Cored } \\
(\mathrm{m})\end{array}$ & $\begin{array}{l}\text { Recovered } \\
(\mathrm{m})\end{array}$ & $\begin{array}{c}\text { Recovery } \\
\text { (\%) }\end{array}$ & $\begin{array}{c}\text { Drilled } \\
(\mathrm{m})\end{array}$ & $\begin{array}{c}\text { Total } \\
\text { penetration } \\
(\mathrm{m})\end{array}$ & $\begin{array}{l}\text { Total } \\
\text { depth } \\
\text { (mbrf) }\end{array}$ & $\begin{array}{l}\text { Time on } \\
\text { hole } \\
\text { (h) }\end{array}$ & $\begin{array}{c}\text { Time on } \\
\text { site } \\
\text { (days) }\end{array}$ \\
\hline \multirow[t]{3}{*}{ U1378 } & A & $08^{\circ} 35.5415^{\prime} \mathrm{N}$ & $084^{\circ} 04.6313^{\prime} \mathrm{W}$ & 536.6 & 0 & 0.0 & 0.00 & 0.00 & 456.9 & 456.9 & 993.5 & 64.50 & 2.7 \\
\hline & B & $08^{\circ} 35.5408^{\prime} \mathrm{N}$ & $084^{\circ} 04.6315^{\prime} \mathrm{W}$ & 533.2 & 63 & 523.9 & 526.39 & 100.48 & 0.0 & 523.9 & 1057.1 & 105.75 & 4.4 \\
\hline & & & Site U13 & 378 totals: & 63 & 523.9 & 526.39 & 100.50 & 456.9 & 980.8 & NA & 170.25 & 7.1 \\
\hline \multirow[t]{4}{*}{ U1379 } & A & $08^{\circ} 40.8501^{\prime} \mathrm{N}$ & $084^{\circ} 02.0166^{\prime} \mathrm{W}$ & 137.0 & 0 & 0.0 & 0.00 & 0.00 & 962.8 & 962.8 & 1099.8 & 91.25 & 3.8 \\
\hline & B & $08^{\circ} 40.8502^{\prime} \mathrm{N}$ & $084^{\circ} 02.0277^{\prime} \mathrm{W}$ & 138.5 & 2 & 10.5 & 8.72 & 83.00 & 0.0 & 10.5 & 149.0 & 5.00 & 0.2 \\
\hline & C & $08^{\circ} 40.8605^{\prime} \mathrm{N}$ & $084^{\circ} 02.0274^{\prime} \mathrm{W}$ & 138.8 & 118 & 949.0 & 815.56 & 85.90 & 0.0 & 949.0 & 1087.8 & 191.25 & 8.0 \\
\hline & & & Site U13 & 379 totals: & 120 & 959.5 & 824.28 & 85.90 & 962.8 & 1922.3 & NA & 287.50 & 12.0 \\
\hline \multirow[t]{2}{*}{ U1380 } & A & $08^{\circ} 35.9976^{\prime} \mathrm{N}$ & $084^{\circ} 04.4032^{\prime} \mathrm{W}$ & 515.0 & 9 & 85.4 & 52.37 & 61.32 & 397.0 & 482.4 & 997.4 & 46.50 & 1.9 \\
\hline & & & Site U13 & 380 totals: & 9 & 85.4 & 52.37 & 61.30 & 397.0 & 482.4 & NA & 46.50 & 1.9 \\
\hline \multirow[t]{4}{*}{ U1381 } & A & $08^{\circ} 25.7150^{\prime} \mathrm{N}$ & $084^{\circ} 09.4690^{\prime} \mathrm{W}$ & 2080.2 & 29 & 164.1 & 73.86 & 45.01 & 0.0 & 164.1 & 2244.3 & 76.75 & 3.2 \\
\hline & B & $08^{\circ} 25.7149^{\prime} \mathrm{N}$ & $084^{\circ} 09.4805^{\prime} \mathrm{W}$ & 2080.2 & 3 & 29.0 & 15.98 & 55.10 & 61.0 & 90.0 & 2170.2 & 16.75 & 0.7 \\
\hline & & & Site U13 & 381 totals: & 32 & 193.1 & 89.84 & 46.50 & 61.0 & 254.1 & NA & 93.50 & 3.9 \\
\hline & & & Expedition 3 & 334 totals: & 224 & 1761.9 & 1492.88 & 84.70 & 1816.7 & 3639.6 & NA & 597.80 & 24.9 \\
\hline
\end{tabular}

$\mathrm{NA}=$ not applicable. 